Proc. Estonian Acad. Sci. Geol., 2006, 55, 4, 269-295

\title{
Diagenetic influences on iron-bearing minerals in Devonian carbonate and siliciclastic rocks of Estonia
}

\author{
Alla Shogenova and Anne Kleesment \\ Institute of Geology at Tallinn University of Technology, Ehitajate tee 5, 19086 Tallinn, Estonia;
} alla@gi.ee

Received 21 February 2006, in revised form 22 June 2006

\begin{abstract}
The Estonian Devonian sediments consist of carbonate, siliciclastic, and mixed carbonatesiliciclastic deposits that have undergone extensive dolomitization. Chemical analysis of 165 samples and XRD mineralogical analysis of 10 samples from 8 drill cores were carried out and combined with previous results, obtained particularly on the heavy and clay fraction residues of 131 samples. The carbonate residues include illite, illite-smectite, and chlorite, with accessory biotite, muscovite, pyrite, goethite, hematite, siderite, sphalerite, and magnetite. The residues of siliciclastic rocks consist of quartz, K-feldspar, illite, montmorrilonite-chlorite and chlorite, with accessory biotite, muscovite, leucoxene, ilmenite, pyrite, hematite, goethite, and siderite. The iron content of rocks is related to the detrital input during primary sedimentation or diagenetic products formed during cementation, dolomitization, and authigenic mineral growth. Iron minerals underwent chemical alteration during diagenesis and are partly corroded and dissolved. Fe(III) minerals, responsible for red coloration of rocks, became dominant due to oxidation, low water table, and arid climate, which prevailed during diagenesis. The red coloration of siliciclastic rocks is due to hematite coatings of quartz grains. It may be primary in origin, but also diagenetic due to alterations of magnetite to hematite and dispersed distribution of Fe-oxides in dolomite cement. The red coloration of carbonate rocks (dolostones and marlstones) may have an early diagenetic origin prior to dolomitization, with possible redistribution of colour at later diagenetic stages. The variable origin of iron minerals (primary, early, middle, and late diagenetic) is distinguishable by thin-section petrography, and can be also supported by chemical and mineralogical data. The average $\mathrm{Fe}_{2} \mathrm{O}_{3 \text { total }} / \mathrm{Al}_{2} \mathrm{O}_{3}$ ratio in the studied carbonates is higher than in siliciclastics, being in accordance with the distribution of these elements in the Earth's crust. In contrast to the Earth's crust data, the average $\mathrm{TiO}_{2} / \mathrm{Al}_{2} \mathrm{O}_{3}$ and $\mathrm{K}_{2} \mathrm{O} / \mathrm{Al}_{2} \mathrm{O}_{3}$ ratios are higher in Devonian siliciclastics. This could be explained by alteration of clay during late diagenesis.
\end{abstract}

Key words: Devonian, diagenesis, carbonate rocks, siliciclastic rocks, mixed carbonate-siliciclastic rocks, iron minerals, insoluble residue, Baltic basin. 


\section{INTRODUCTION}

This is the first of the two papers dealing with the chemico-mineralogical influence of diagenetic processes on Devonian carbonate and siliciclastic rocks of Estonia. Here the results of previous geochemical, mineralogical, and petrographical studies are supplemented by new data from eight drill cores (Fig. 1). A second forthcoming article will consider the rock magnetic properties of the same sequences. The initial study (Shogenova 1999) revealed the importance of diagenetic processes in Estonian Palaeozoic rocks, but the problems are wideranging in both space and time (Haese et al. 1998; Haubold 1999; Marton 1999; Wilson \& Roberts 1999). Recent interest has focused on processes related to diagenesis (Passier et al. 2001; Lewchuk et al. 2002; Schneider et al. 2004a, b). The main event of the Hercynian orogeny in Europe was the consolidation of mountain-fold belts. As the Baltic Devonian sedimentary basin was located in the northwestern part of the East European Craton, it lay in the equatorial region of the Laurussia continent that formed at the end of the Silurian (Ziegler 1988). Both tectonic movements and eustatic sea-level oscillations influenced the development of sedimentary sequences in this region (Ziegler 1988; Mokrik 2003). Epicontinental shallow sea sediments have a complex cyclic structure in which siliciclastic and carbonate sediments alternate recurrently. Pure dolostone, dolomitic marlstone, siliciclastic sediments, and mixed carbonate-siliciclastic rocks are represented in southern and southeastern Estonia (Kleesment \& Shogenova 2005). The thickness of the Devonian sequence in the eight studied boreholes (Fig. 1) is from $111 \mathrm{~m}$ in the Häädemeeste core up to $352 \mathrm{~m}$ in the Vorru core (Kleesment \& Shogenova 2005).

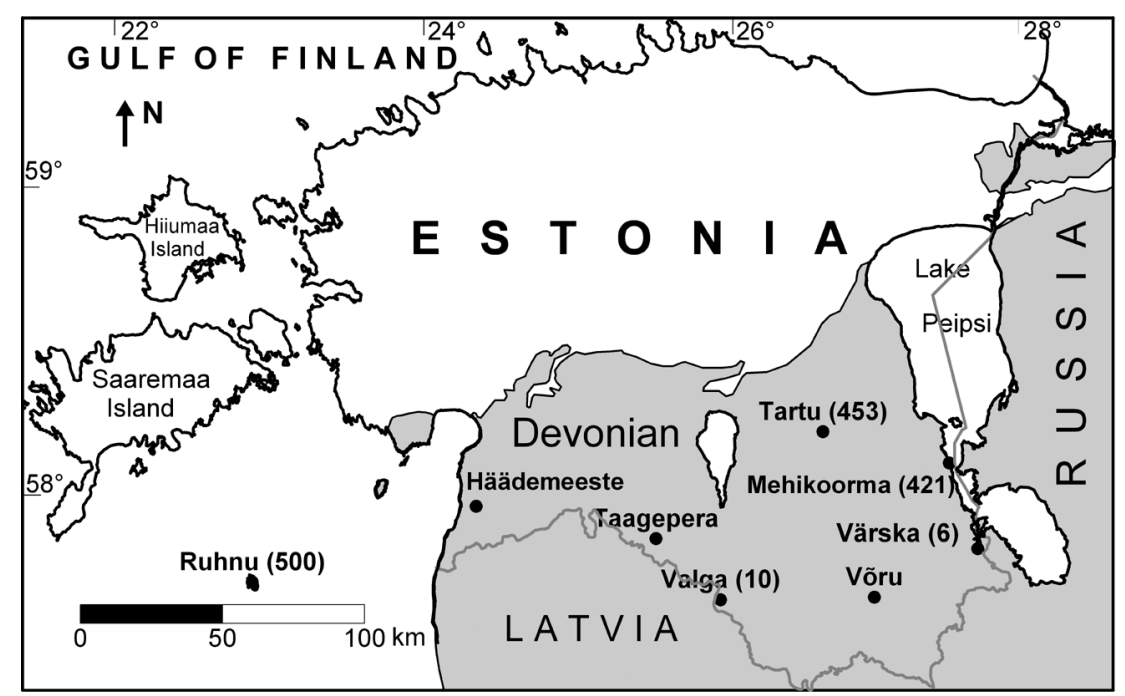

Fig. 1. Distribution of Devonian rocks (grey shading) and location of the sampled boreholes. 
The main influx of siliciclastic material was from the Scandinavian granite massifs (Kuršs 1992; Kleesment 1997; Plink-Björklund \& Björklund 1999), while the carbonate sediments are mostly represented by dolostones. The Devonian sediments overlie with a stratigraphical gap the Silurian or Ordovician (Kleesment \& Shogenova 2005). The Estonian part of the Baltic Devonian basin is unique as here the alternating carbonate, siliciclastic, and mixed carbonate-siliciclastic rocks have been influenced by subsequent diagenetic dolomitization episodes during which a number of minerals (feldspar, pyrite, goethite, gypsum) were formed. These and primary minerals were later partly corroded, dissolved, and recrystallized by diagenetic fluids (Kleesment 1984, 1998). The sediment sequences of the area thus contain mixed rocks of primary and secondary genesis (Kleesment $\&$ Shogenova 2005). Some of iron-bearing minerals, of primary and diagenetic origin, are responsible for colours ranging from pink to red and red-grey mottled varieties that also vary between carbonate and siliciclastic rocks (Fig. 2). Several authors have studied diagenesis in the southern part of the Baltic Devonian basin (e.g. Narbutas 1981; Simaškaite \& Simkevičius 1981). The influence of different iron-bearing minerals has been interpreted considering the red colouring of Devonian siliciclastic rocks (Kuršs \& Stinkule 1972). Diagenetic replacement of magnetite by goethite in siliciclastic rocks has mostly been described in sections with thin intercalations of siliciclastic and clayey-dolomitic rocks (Paluskova 1988; Abdalla et al. 1997). The replacement of ilmenite by leucoxene during diagenesis has been known for a long time, but is often ascribed to different stages from early diagenesis in mildly reducing and neutral-acid tropical conditions (Weibel 2003) to late diagenesis (Al-Juboury et al. 1994). The alteration of ilmenite is an important source of iron for diagenetic minerals (Pe-Piper et al. 2005). As published data on the chemical composition of the Baltic Devonian rocks are scarce, here mainly the results of Shogenova et al. (2003a, b) and Kleesment \& Shogenova (2005) are used. The influence of dolomitization on the composition and properties of Estonian carbonates has earlier been studied in Ordovician and Silurian rocks (Shogenova \& Puura 1997, 1998; Shogenova 1999). However, this phenomenon also occurs in the Devonian of southern Estonia and possibly all these areas are affected by Devonian dolomitization fluids. An increase in the total iron content and magnetic parameters has been recorded in the Ordovician, and to some extent Silurian dolostones in comparison with limestones of these ages. The influence of dolomite cement on siliciclastic rocks has been described for Cambrian rocks of Estonia (Shogenova et al. 2001) and in the southern part of the Baltic Cambrian basin (Šliaupa et al. 2001, 2003).

Diagenesis is defined as a series of chemical, physical, and biological processes leading to a significant change in sediments, which started after their deposition and continued during and after their lithification (Larsen \& Chilingar 1979; Morse \& Mackenzie 1990). Carbonate diagenesis includes such major processes as cementation, microbial micritization, neomorphism, dissolution, compaction, and dolomitization and it operates in three main environments: marine, nearsurface meteoritic, and burial (Tucker \& Wright 1994). Diagenesis of siliciclastic 


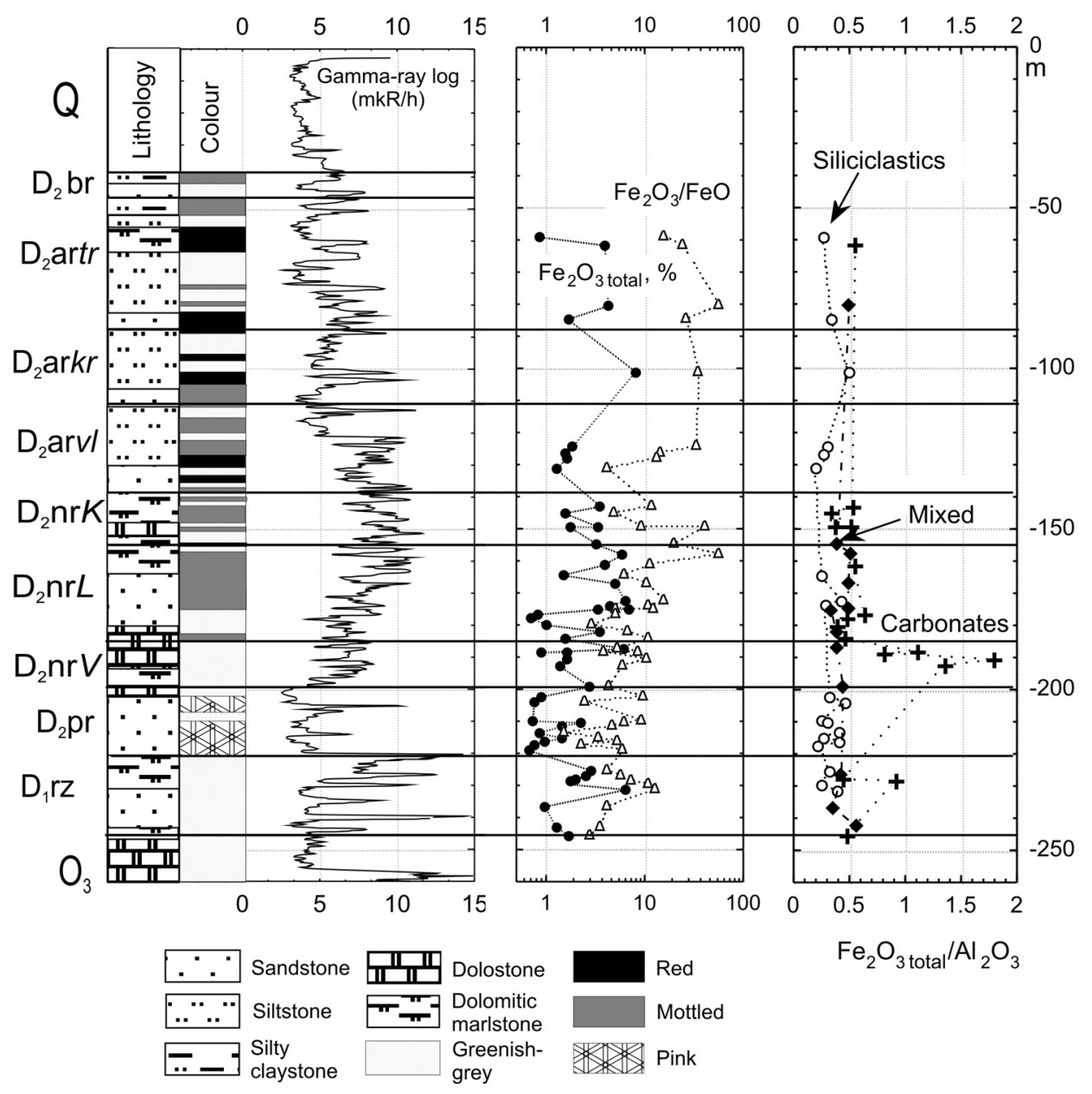

Fig. 2. Lithology, colour, and gamma-ray log of the Mehikoorma (421) drill core. The total iron content (filled circles) of core samples and their $\mathrm{Fe}_{2} \mathrm{O}_{3} / \mathrm{FeO}$ ratio (open triangles) are shown in a log-decimal scale. In addition, the $\mathrm{Fe}_{2} \mathrm{O}_{3 \text { total }} / \mathrm{Al}_{2} \mathrm{O}_{3}$ ratio is shown for siliciclastic rocks (open circles), mixed rocks (filled diamonds), and carbonate rocks (crosses). The Devonian is represented by the top of the Emsian Stage (Rezekne Regional Stage, $D_{1}$ rz), Eifelian Stage including the Pärnu $\left(\mathrm{D}_{2} \mathrm{pr}\right)$, Narva $\left(\mathrm{D}_{2} \mathrm{nr}\right)$, and Aruküla $\left(\mathrm{D}_{2}\right.$ ar) regional stages, and the oldest part of the Givetian Stage - Burtnieki Regional Stage $\left(\mathrm{D}_{2} \mathrm{br}\right)$. The Narva Regional Stage is subdivided into the Vadja $\left(\mathrm{D}_{2} \mathrm{nr} V\right)$, Leivu $\left(\mathrm{D}_{2} \mathrm{nr} L\right)$, and Kernave $\left(\mathrm{D}_{2} \mathrm{nr} K\right)$ formations and the Aruküla Regional Stage into the Viljandi $\left(\mathrm{D}_{2} \operatorname{ar} v\right)$, Kureküla $\left(\mathrm{D}_{2} \mathrm{arkr}\right)$, and Tarvastu $\left(\mathrm{D}_{2} \mathrm{ar} t r\right)$ members (Kleesment \& Shogenova 2005).

rocks includes compaction, cementation, reworking, authigenesis, replacement, recrystallization, leaching, hydration, bacterial actions, and formation of concretions.

The division of diagenesis most widely accepted in the scientific literature has three stages: early (immediately after deposition), middle (deep burial), and late (during and after uplift) (Fairbridge 1967). Late diagenesis was followed by weathering (Larsen \& Chilingar 1979). 
In case of siliciclastic rocks, because of oxidation and reduction reactions, diagenesis is subdivided into the redoxomorphic, locomorphic, and phyllomorphic stages. The redoxomorphic stage is mostly responsible for the bulk final colour of the rock, while later changes in rock colour are smaller. During the second stage primary cementation develops and the rock becomes lithified. Authigenic overgrowth and clay alteration take place during the third stage (Dapples 1979).

During the redoxomorphic stage iron is moved into the ferrous state and sulphur is fixed as pyrite, which is scattered throughout the rock. If an organic fraction is significant, the rock has grey colour (Love 1971). Red colour may appear in oxidizing conditions when detrital iron oxides or clay minerals are transformed into hematite and related ferric oxides and hydrates, occurring in the form of films, matrix or pore filling.

\section{DATA AND METHODS}

The bulk chemical composition $\left(\mathrm{SiO}_{2}, \mathrm{Al}_{2} \mathrm{O}_{3}, \mathrm{TiO}_{2}, \mathrm{~K}_{2} \mathrm{O}, \mathrm{Na}_{2} \mathrm{O}, \mathrm{Fe}_{2} \mathrm{O}_{3 \text { total }}\right.$, $\mathrm{CaO}, \mathrm{MgO}, \mathrm{MnO}$, and $\mathrm{P}_{2} \mathrm{O}_{5}$ contents) of 165 samples from eight boreholes was determined by X-ray fluorescence analysis in the All-Russian Geological Institute, St. Petersburg, using the method described in Teedumäe et al. (2006). The insoluble residue (IR) and $\mathrm{FeO}$ contents were measured by wet chemical analysis at the Institute of Geology at Tallinn University of Technology. The Pearson correlation was calculated for the pairs of measured parameters, without logarithmic transformation.

\section{Chemical analyses}

The IR was determined gravimetrically using carbonate wet chemical analysis. An amount of $50 \mathrm{~mL}$ of $\mathrm{HCl}(1: 4)$ was added to $0.5 \mathrm{~g}$ of rock powder and dried in a water bath. The remaining residue was mixed with $5 \mathrm{~mL}$ of concentrated $\mathrm{HCl}$ and $30-40 \mathrm{~mL}$ of hot water $\left(90-100^{\circ} \mathrm{C}\right)$, filtrated and washed with hot water $\left(90-100^{\circ} \mathrm{C}\right)$. The filtrated residue was heated to $1000^{\circ} \mathrm{C}$ for one hour and then weighed. The concentration of ferrous oxide $(\mathrm{FeO})$ was determined photocolorometrically with $\alpha-\alpha$ dypirisol $\left(\mathrm{C}_{12} \mathrm{H}_{8} \mathrm{~N}_{2}\right)$. Fe $\mathrm{Fe}^{2+}$ forms with $\alpha-\alpha$ dypirisol an orangered water soluble complex with $\mathrm{pH}=4$. It is stable in respect to oxygen and over long time periods. The colour appears very fast and depends strongly on Beer's law for wide ranges of $\mathrm{Fe}^{2+}$ concentrations. The maximum photoabsorbability occurs at $505 \mathrm{~nm}$ wavelength.

Silicate rocks and minerals were decomposed by a mixture of $\mathrm{HF}$ and $\mathrm{H}_{2} \mathrm{SO}_{4}$. The solution was boiled for $5 \mathrm{~min}$ so that the carbonate rocks were decomposed by $\mathrm{H}_{2} \mathrm{SO}_{4}$. The value $\mathrm{pH}=4$ was controlled by the $\mathrm{H}_{3} \mathrm{BO}_{3}$ solution. This method allows the $\mathrm{FeO}$ concentration in the range of $0.1-20 \%$ to be determined in samples with a mass between 0.1 and $0.5 \mathrm{~g}$. 


\section{Mineralogical analysis}

Mineralogical analysis of the clay fraction and heavy minerals has earlier been carried out in the same boreholes, though on different samples. The mineralogical composition of the clay fraction of 81 samples from three boreholes was studied using the URS-50 IM and Dron-1 diffractometers, allowing the identification of the main minerals with an accuracy of about $5 \%$ (Fe-filtered $\mathrm{Co}$ - and $\mathrm{Cu}$-radiation; Utsal 1971; Stinkule \& Utsal 1975). The mineralogical composition of heavy minerals in 131 samples from four boreholes was determined in immersion liquids under a microscope using plane-polarized, transmitted light. Samples with dolomite cement were crushed and dissolved in $10 \%$ acetic acid and IR grains with a diameter of $<0.01 \mathrm{~mm}$ were removed by washing. Grains $>0.01 \mathrm{~mm}$ were separated by sieving and studied in transmitted and reflected light under the binocular $(\mathrm{BM})$ and petrographic microscope (PM). The $0.05-0.1 \mathrm{~mm}$ fraction was separated using bromoform and the light and heavy minerals were determined separately by the immersion method under the PM in plane and cross-polarized light. About 300-500 grains were counted for each mineral spectrum and expressed in per cent (Kleesment \& Valiukevičius 1998; Kleesment 2001, 2003). Ilmenite, magnetite, pyrite, and garnet were determined by microscopical analysis. Grains $>0.1 \mathrm{~mm}$ were investigated using the BM. The content of magnetite was estimated roughly with a magnet and, in some samples, the occurrence of magnetite was checked using XRD techniques. Pyrite was identified in thin sections and in immersion liquid. In addition, during the present study the bulk mineral composition of 10 samples was determined using the HZG4 diffractometer (Fe-filtered Co-radiation). For these analysis sample powders were mixed with alcohol and spread on glass slides. A range from 5 to $40^{\circ} 2 \theta$ was step-scanned (step $0.05^{\circ} 2 \theta$, counting rate $3 \mathrm{~s}$ ). Additionally 55 thin sections were studied under the PM with up to 200 times magnification.

\section{RESULTS \\ Composition of the studied rocks}

\section{Chemical composition}

The samples can be subdivided into four lithological groups based on chemical parameters (Kleesment \& Shogenova 2005). As the carbonate rocks in the eight boreholes considered are almost fully dolomitized, four general rock types could be identified using only one chemical parameter - IR. From 165 rock samples, the following rock types were obtained (Fig. 3, Table 1):

(1) dolostones (IR $<25 \%)-40$ samples;

(2) dolomitic marlstones $(25 \%<$ IR $<50 \%)-29$ samples;

(3) mixed carbonate-siliciclastic rocks $(50 \%<$ IR $<70 \%)-39$ samples represented by dolostones, dolomitic marlstones, siltstones, and sandstones;

(4) siliciclastic rocks (IR $>70 \%$ ) -57 samples represented by cemented sandstones, siltstones, and mudstones. 


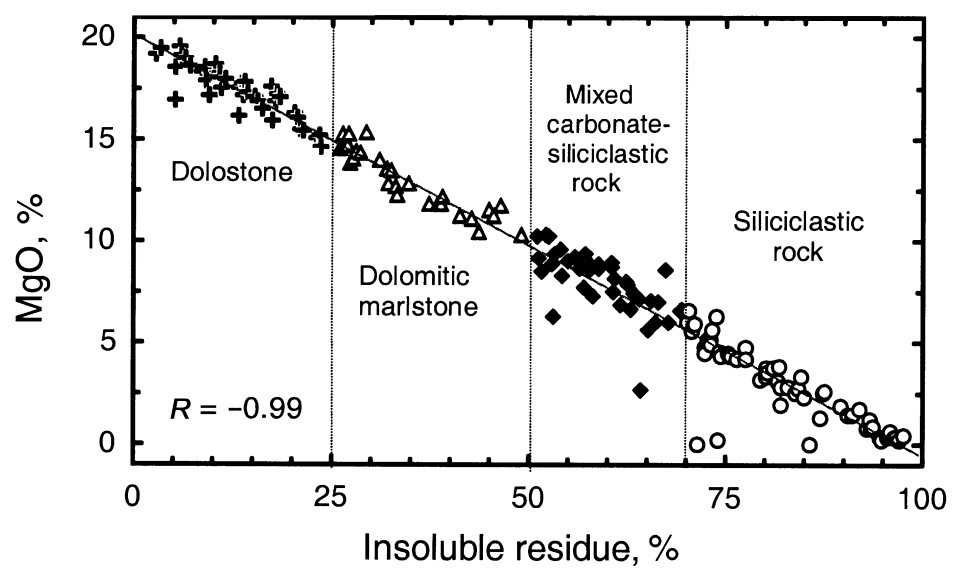

Fig. 3. $\mathrm{MgO}$ content by XRF data versus IR content by wet chemical analysis. Mixed and siliciclastic rock samples, located away from the correlation line, include gypsum and calcite cement.

The first type includes dolostones from pure dolomite to strongly argillaceous rock, with an IR content between 2.7 and $23.5 \%$ and $\mathrm{MgO}$ content of $14.5-19.9 \%$ (Table 1). Dolostones had the lowest average total iron content (1.56\%), but the highest ratios of $\mathrm{Fe}_{2} \mathrm{O}_{3 \text { total }} / \mathrm{Al}_{2} \mathrm{O}_{3}, \mathrm{Fe}_{2} \mathrm{O}_{3 \text { total }} / \mathrm{K}_{2} \mathrm{O}$, and $\mathrm{Fe}_{2} \mathrm{O}_{3 \text { total }} / \mathrm{TiO}_{2}$ (Table 1, Figs 2, 4a-c). The content of oxides $\left(\mathrm{Al}_{2} \mathrm{O}_{3}, \mathrm{~K}_{2} \mathrm{O}, \mathrm{TiO}_{2}\right)$ in the IR, which reflects the clay content of the rocks, $\mathrm{SiO}_{2}$ content, total iron content, and $\mathrm{K}_{2} \mathrm{O} / \mathrm{Al}_{2} \mathrm{O}_{3}$ and $\mathrm{TiO}_{2} / \mathrm{Al}_{2} \mathrm{O}_{3}$ ratios were the lowest in dolostones in comparison with the other rock types. The average $\mathrm{FeO}$ content $(0.16 \%)$ and $\mathrm{Fe}_{2} \mathrm{O}_{3} / \mathrm{FeO}$ ratio were also the lowest among the studied rock types. The $\mathrm{FeO}$ content of dolostones was not dependent on the total iron and $\mathrm{TiO}_{2}$ contents (Table 1, Fig. 4d-f).

Dolomitic marlstones contain $25.9-49 \%$ IR and $10.3-16 \% \mathrm{MgO}$. Total iron, $\mathrm{Al}_{2} \mathrm{O}_{3}, \mathrm{~K}_{2} \mathrm{O}$, and $\mathrm{TiO}_{2}$ contents, and $\mathrm{K}_{2} \mathrm{O} / \mathrm{Al}_{2} \mathrm{O}_{3}$ and $\mathrm{TiO}_{2} / \mathrm{Al}_{2} \mathrm{O}_{3}$ ratios were higher than in dolostones, while $\mathrm{Fe}_{2} \mathrm{O}_{3 \text { total }} / \mathrm{Al}_{2} \mathrm{O}_{3}, \mathrm{Fe}_{2} \mathrm{O}_{3 \text { total }} / \mathrm{K}_{2} \mathrm{O}$, and $\mathrm{Fe}_{2} \mathrm{O}_{3 \text { total }} / \mathrm{TiO}_{2}$ ratios were lower (Table 1, Fig. $4 \mathrm{a}-\mathrm{c}$ ). The $\mathrm{FeO}$ content was on average $(0.23 \%)$ higher than in dolostones, but the $\mathrm{Fe}_{2} \mathrm{O}_{3} / \mathrm{FeO}$ ratio was in the same limits (Table 1; Figs 2, 4d-e). The $\mathrm{Fe}_{2} \mathrm{O}_{3 \text { total }} / \mathrm{Al}_{2} \mathrm{O}_{3}, \mathrm{Fe}_{2} \mathrm{O}_{3 \text { total }} / \mathrm{K}_{2} \mathrm{O}$, and $\mathrm{Fe}_{2} \mathrm{O}_{3 \text { total }} / \mathrm{TiO}_{2}$ ratios in carbonate rocks (dolostones and dolomitic marlstones) were higher than in mixed and siliciclastic rocks (Table 1; Figs 2, 4a-c). The correlation of the total iron content with $\mathrm{Al}_{2} \mathrm{O}_{3}, \mathrm{~K}_{2} \mathrm{O}$, and $\mathrm{TiO}_{2}$, contents of carbonate rocks (dolostones and dolomitic marlstones) taken together was relatively high (correlation coefficients $0.84,0.76$, and 0.82 , respectively), but the correlation was negative with $\mathrm{MgO}$ and $\mathrm{CaO}$ contents $(-0.63$ and -0.7 ; Fig. $4 \mathrm{~d})$.

Siliciclastic rocks are represented by sand- and siltstones with cement consisting of clay, dolomite and iron-bearing minerals. They contain $70.2-97.6 \%$ IR and $0.14-6.6 \% \mathrm{MgO}$. Three siliciclastic samples which lie away from the correlation line (Fig. 3) contained calcite (Värska (6) borehole) and gypsum cement (Värska (6) 
Table 1. Chemical composition of rocks*

\begin{tabular}{|c|c|c|c|c|}
\hline \multirow[t]{3}{*}{ Studied parameter } & \multicolumn{4}{|c|}{ Rock type } \\
\hline & Dolostones & $\begin{array}{l}\text { Dolomitic } \\
\text { marlstones }\end{array}$ & $\begin{array}{l}\text { Mixed carbonate- } \\
\text { siliciclastic rocks }\end{array}$ & $\begin{array}{l}\text { Siliciclastic } \\
\text { rocks }\end{array}$ \\
\hline & \multicolumn{4}{|c|}{$\begin{array}{l}\text { Min-Max/Avg } \\
\text { Std. Dev. }(N)\end{array}$} \\
\hline \multirow[t]{2}{*}{ Insoluble residue, \% } & $\underline{2.7-23.5 / 13.2}$ & $\underline{25.9-49 / 34.3}$ & $\underline{51-69.4 / 59.5}$ & $\underline{70.2-97.6 / 83}$ \\
\hline & $5.8(40)$ & $7.2(29)$ & $5.5(37)$ & $8.9(54)$ \\
\hline \multirow[t]{2}{*}{$\mathrm{MgO}, \%$} & $\underline{14.5-19.9 / 17.7}$ & $\underline{10.3-16 / 13.3}$ & $\underline{6-11 / 8.4}$ & $\underline{0.14-6.6 / 3.1}$ \\
\hline & $1.5(40)$ & $1.8(29)$ & $\overline{1.2(37)}$ & $2(54)$ \\
\hline \multirow[t]{2}{*}{$\mathrm{CaO}, \%$} & $22-31.7 / 26.3$ & $\underline{13.2-21.9 / 18.2}$ & $\underline{1.1-16.1 / 10.5}$ & $\underline{0.15-10.8 / 3.9}$ \\
\hline & $2.4(40)$ & $2.6(29)$ & $3.1(37)$ & $3.2(54)$ \\
\hline \multirow[t]{2}{*}{$\mathrm{SiO}_{2}, \%$} & $\underline{0.74-17.5 / 10}$ & $\underline{19.1-44.3 / 27.6}$ & $\underline{36.1-66.5 / 49.8}$ & 53.6-94.7/71.3 \\
\hline & $4.6(40)$ & $7(29)$ & $7.8(37)$ & $12.6(54)$ \\
\hline \multirow[t]{2}{*}{$\mathrm{Al}_{2} \mathrm{O}_{3}, \%$} & $\underline{0.55-5.7 / 2.9}$ & $1.94-12 / 6.24$ & $1.1-16.8 / 7.5$ & $1.64-16.6 / 7.7$ \\
\hline & $\frac{1.4(40)}{1.0}$ & $2.2(29)$ & $4.2(37)$ & $3.8(54)$ \\
\hline \multirow[t]{2}{*}{$\mathrm{K}_{2} \mathrm{O}, \%$} & $\underline{0.2-1.9 / 1}$ & $\underline{1.4-3.9 / 2.5}$ & $\underline{0.9-6.5 / 3.6}$ & $\underline{1.22-8.7 / 4.5}$ \\
\hline & $0.49(40)$ & $0.55(29)$ & $1.5(37)$ & $1.7(54)$ \\
\hline \multirow[t]{2}{*}{$\mathrm{TiO}_{2}, \%$} & $\leq 0.005-0.26 / 0.11$ & $\underline{0.14-0.47 / 0.31}$ & $\underline{0.01-0.8 / 0.4}$ & $\underline{0.063-0.99 / 0.46}$ \\
\hline & $0.06(40)$ & $0.08(29)$ & $0.2(37)$ & $0.22(54)$ \\
\hline \multirow[t]{2}{*}{$\mathrm{K}_{2} \mathrm{O} / \mathrm{Al}_{2} \mathrm{O}_{3}$} & $\underline{0.08-0.48 / 0.36}$ & $\underline{0.24-0.7 / 0.43}$ & $\underline{0.3-0.87 / 0.55}$ & $\underline{0.38-0.78 / 0.62}$ \\
\hline & $0.08(40)$ & $0.11(29)$ & $0.15(37)$ & $0.1(54)$ \\
\hline \multirow[t]{2}{*}{$\mathrm{TiO}_{2} / \mathrm{Al}_{2} \mathrm{O}_{3}$} & $\underline{0.001-0.05 / 0.04}$ & $\underline{0.035-0.08 / 0.05}$ & $\underline{0.003-0.09 / 0.05}$ & $\underline{0.022-0.18 / 0.06}$ \\
\hline & $0.01(40)$ & $0.01(29)$ & $0.02(37)$ & $0.02(54)$ \\
\hline \multirow[t]{2}{*}{$\mathrm{Fe}_{2} \mathrm{O}_{3 \text { total }}, \%$} & $\underline{0.63-3.3 / 1.56}$ & $\underline{0.9-5.5 / 2.62}$ & $\underline{0.4-7.5 / 3.1}$ & $\underline{0.45-9.1 / 2.57}$ \\
\hline & $0.5(40)$ & $1.1(29)$ & $2.0(37)$ & $2(54)$ \\
\hline \multirow[t]{2}{*}{$\mathrm{FeO}, \%$} & $\underline{0.03-0.43 / 0.16}$ & $\underline{0.03-0.43 / 0.23}$ & $\underline{0.01-0.94 / 0.24}$ & $\underline{0.05-0.52 / 0.19}$ \\
\hline & $0.11(40)$ & $0.1(29)$ & $0.21(37)$ & $0.11(54)$ \\
\hline \multirow[t]{2}{*}{$\mathrm{Fe}_{2} \mathrm{O}_{3} / \mathrm{FeO}$} & $\underline{2.5-51 / 13.7}$ & $\underline{2.6-50 / 14}$ & $\underline{3.6-93 / 19}$ & $\underline{1-41 / 15.5}$ \\
\hline & $12.8(40)$ & $12.3(29)$ & $18.7(37)$ & $10.5(54)$ \\
\hline \multirow[t]{2}{*}{$\mathrm{Fe}_{2} \mathrm{O}_{3 \text { total }} / \mathrm{Al}_{2} \mathrm{O}_{3}$} & $\frac{0.29-3.15 / 0.68}{0.510)}$ & $\underline{0.21-0.91 / 0.43}$ & $\underline{0.11-0.71 / 0.41}$ & $\frac{0.1-0.58 / 0.31}{0.154}$ \\
\hline & $0.51(40)$ & $0.13(29)$ & $0.11(37)$ & $0.1(54)$ \\
\hline
\end{tabular}

* Five samples with calcite and gypsum cement are not included in the table. Std. Dev., standard deviation.

and Vorru boreholes). The total iron content varied largely (0.45-9.1\%), however, the average value $(2.6 \%)$ was close to that of marlstones and mixed rocks (Fig. 4a-d, Table 1). The $\mathrm{Al}_{2} \mathrm{O}_{3}, \mathrm{~K}_{2} \mathrm{O}$, and $\mathrm{TiO}_{2}$ contents of the siliciclastic rocks and the $\mathrm{K}_{2} \mathrm{O} / \mathrm{Al}_{2} \mathrm{O}_{3}$ and $\mathrm{TiO}_{2} / \mathrm{Al}_{2} \mathrm{O}_{3}$ ratios were the highest among the studied rock types (Fig. 4a-c, Table 1). Correlation of the total iron content with $\mathrm{Al}_{2} \mathrm{O}_{3}$, $\mathrm{K}_{2} \mathrm{O}$, and $\mathrm{TiO}_{2}$ was also high (coefficients $0.89,0.68$, and 0.88 , respectively), but there was no significant correlation with carbonate components $(\mathrm{CaO}$ and $\mathrm{MgO}$; Fig. $4 a-d)$. Aluminium oxide has entered mainly clay minerals, titanium oxide reflects titanium minerals, and potassium oxide has entered both clay minerals and $\mathrm{K}$-feldspar in these rocks. 
The $\mathrm{Fe}_{2} \mathrm{O}_{3 \text { total }} / \mathrm{Al}_{2} \mathrm{O}_{3}, \mathrm{Fe}_{2} \mathrm{O}_{3 \text { total }} / \mathrm{K}_{2} \mathrm{O}$, and $\mathrm{Fe}_{2} \mathrm{O}_{3 \text { total }} / \mathrm{TiO}_{2}$ ratios in siliciclastic rocks were lower than in carbonate and mixed rocks. The FeO content was $0.05-$ $0.52 \%$ and had significant, but not high correlation $(R=0.37)$ with the total iron content. The $\mathrm{Fe}_{2} \mathrm{O}_{3 \text { total }} / \mathrm{FeO}$ ratio had the narrowest limits, but on average it was higher than in carbonate rocks.

Mixed rocks include $51-69.4 \%$ IR and $6-11 \% \mathrm{MgO}$. The limits of the total iron content in this group (0.4-7.5\%) were wider than in marlstones and narrower than in siliciclastic rocks, while the average (3.1\%) was higher than in the other rock groups (Table 1). The $\mathrm{Fe}_{2} \mathrm{O}_{3 \text { total }} / \mathrm{Al}_{2} \mathrm{O}_{3}, \mathrm{Fe}_{2} \mathrm{O}_{3 \text { total }} / \mathrm{K}_{2} \mathrm{O}$, and $\mathrm{Fe}_{2} \mathrm{O}_{3 \text { total }} / \mathrm{TiO}_{2}$ ratios were lower than in carbonate, but higher than in siliciclastic rocks (Fig. 4a-c). The $\mathrm{Fe}_{2} \mathrm{O}_{3} / \mathrm{FeO}$ ratio was the highest among the studied rock types. The $\mathrm{TiO}_{2}$, and $\mathrm{Al}_{2} \mathrm{O}_{3}$ contents varied widely (Table 1; Figs 2, 4a,c), while their means and the $\mathrm{TiO}_{2} / \mathrm{Al}_{2} \mathrm{O}_{3}$ ratio were close to those of dolomitic marlstones. The $\mathrm{K}_{2} \mathrm{O}$ content (0.9-6.5\%; Fig. 4b) and average $\mathrm{K}_{2} \mathrm{O} / \mathrm{Al}_{2} \mathrm{O}_{3}$ ratio were higher than in dolomitic marlstones, but lower than in siliciclastic rocks (Table 1). Correlation of the total iron content with $\mathrm{Al}_{2} \mathrm{O}_{3}, \mathrm{~K}_{2} \mathrm{O}$, and $\mathrm{TiO}_{2}$ contents was the highest among all rock groups (coefficients $0.93,0.8$, and 0.87 , respectively; Fig. $4 \mathrm{a}-\mathrm{c}$ ). The correlation coefficients of $\mathrm{FeO}$ with total iron $(R=0.68)$ and $\mathrm{TiO}_{2}$ contents $(R=0.61)$ were higher than for siliciclastic and carbonate rocks.

\section{Lithology and petrography}

Dolostones are light grey to light brownish-grey. The matrix of dolostone is cloudy, and dominantly aphanocrystalline $(<0.004 \mathrm{~mm})$, with rare very fine crystalline grains $(0.005-0.01 \mathrm{~mm})$. The structure is often patchy, due to different clay components and pigmentation from iron minerals. Scattered crystals of pyrite and goethite/hematite (both $0.001-0.005 \mathrm{~mm}$ ) were found in the matrix (Fig. 5a,b). The IR was mainly represented by a muddy fraction $(<0.01 \mathrm{~mm})$ consisting predominantly of illite accompanied by a considerable amount of chlorite. Mixed layers of montmorillonite-chlorite, illite-smectite, illite-chlorite, and illite-montmorillonite also occurred. Dolomitic marlstones are grey, often with violet or greenish shades, mottled reddish-brown (Fig. $5 \mathrm{c}, \mathrm{d}$ ) to greenish-grey, mostly very fine to fine-grained $(0.004-0.01 \mathrm{~mm})$, cloudy or semitransparent (Fig. $5 \mathrm{c}, \mathrm{d})$ and alternating with clay- and dolostone. The structure of the beds is commonly massive. The matrix is pigmented with indistinct patches of hematite or goethite, containing also fine and varied detrital grains. The IR was mainly represented by muddy particles $(<0.01 \mathrm{~mm})$. The muddy fraction was characterized by a high content of illite (60-80\%) accompanied with chlorite. Sometimes an admixture of mixed-layer chlorite-montmorillonite was found (up to 20\%). The content of detrital particles $(>0.01 \mathrm{~mm})$ was $5-20 \%$. The general mineralogical composition of reddish-brown, grey, and pink loosely and carbonate cemented siliciclastic rocks is similar. Quartz accompanied by K-feldspars and mica minerals dominates (Kleesment \& Shogenova 2005). A high variability was observed in the content of accessory minerals. During diagenesis of loosely cemented siliciclastic rocks 

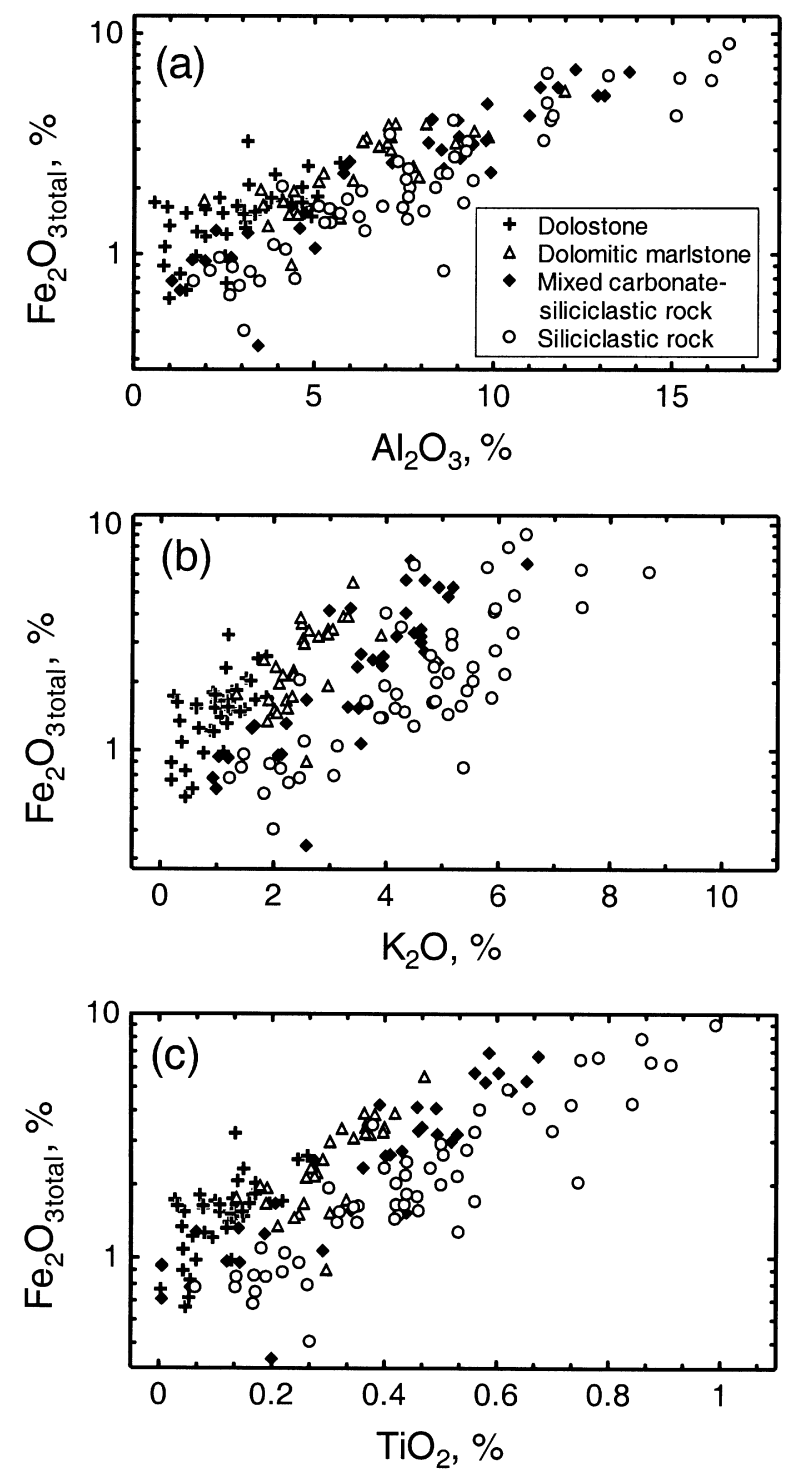

Fig. 4. (a) Total iron content on a log-decimal scale versus $\mathrm{Al}_{2} \mathrm{O}_{3}$ content. The correlation coefficient $R$ of the total iron content and $\mathrm{Al}_{2} \mathrm{O}_{3}$ content is 0.84 for dolostones and dolomitic marlstones, $R=0.93$ for mixed rocks, and $R=0.89$ for siliciclastic rocks. (b) Total iron content on a log-decimal scale versus $\mathrm{K}_{2} \mathrm{O}$ content. $R=0.76$ for dolostones and dolomitic marlstones, $R=0.80$ for mixed rocks, and $R=0.68$ for siliciclastic rocks. (c) Total iron content on a log-decimal scale versus $\mathrm{TiO}_{2}$ content. $R=0.82$ for dolostones and dolomitic marlstones, $R=0.87$ for mixed rocks, and $R=0.88$ for siliciclastic rocks. (d) Total iron content versus $\mathrm{MgO}$ content. $R=-0.63$ for carbonate rocks, and is insignificant for dolomitic marlstones, mixed rocks, and siliciclastic rocks. (e) FeO content on a logdecimal scale versus total iron content. $R=0.68$ for mixed rocks, $R=0.37$ for siliciclastic rocks, and is insignificant for dolostones and dolomitic marlstones. (f) $\mathrm{FeO}$ content versus $\mathrm{TiO}_{2}$ content. $R=0.35$ for siliciclastic rocks and $R=0.61$ for mixed rocks, and is insignificant for dolostones and dolomitic marlstones. 

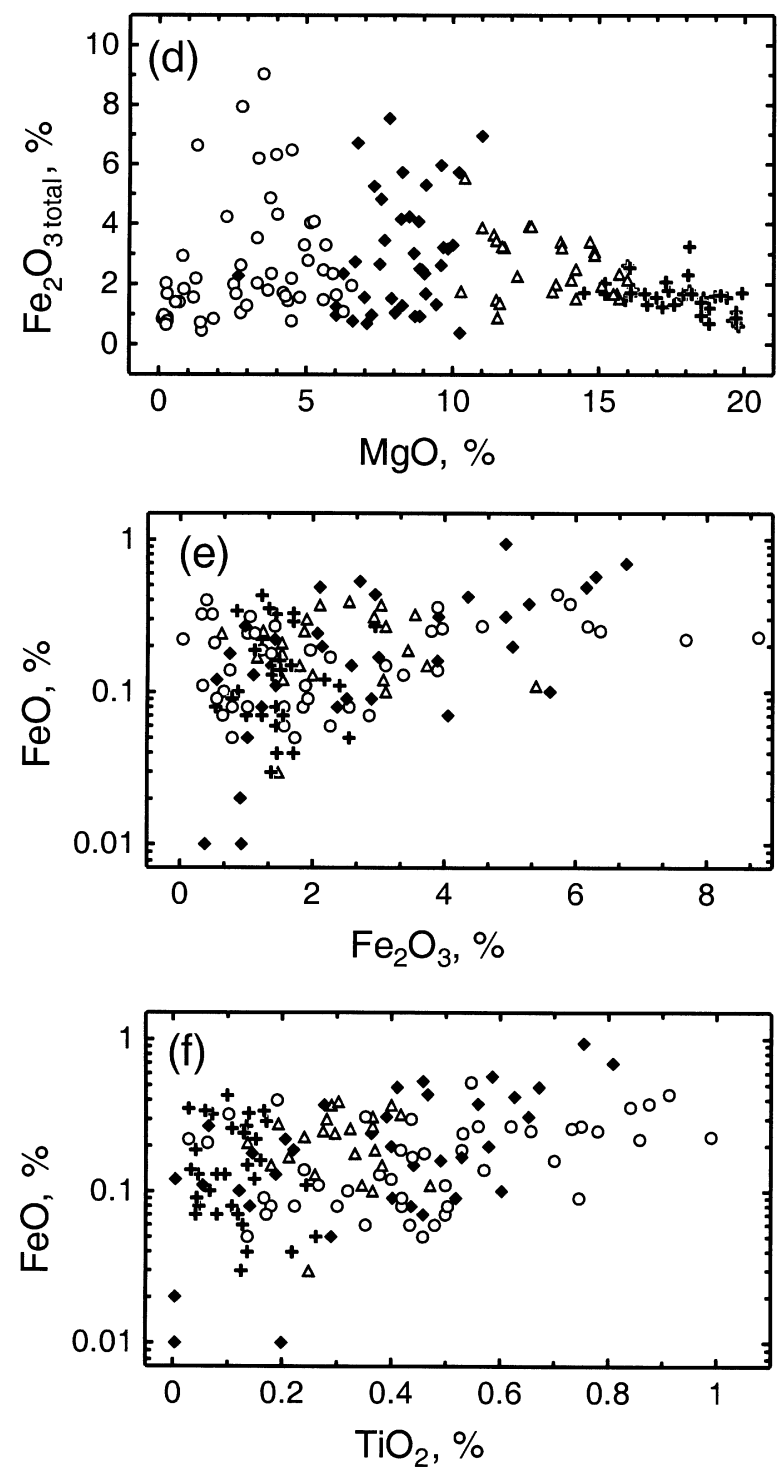

Fig. 4. Continued.

detrital magnetite was replaced by goethite (Kleesment 1984). Cemented siliciclastic rocks have mostly a dolomite matrix. Only in a few cases calcite cement occurred in the lower part of the sequence in East Estonia (Võru core). Some gypsum cemented layers were observed in the Vadja Formation in the Värska (6) core. Usually cement formed $30-40 \%$ (Fig. 6a,b), more rarely $10-30 \%$ of the rock. 
Patchy distribution of cement was common, with grain-supported and cementsupported spots. Pigmentation of the matrix by goethite or hematite was either patchy or appeared along bedding planes (Fig. 6a,b). Occasionally pyrite cement was found.

Varicoloured mixed carbonate-siliciclastic rocks are represented by cementsupported silt- and sandstone, and by dolomitic marlstone and dolostone including siliciclastic material (Fig. 6c). Two mixed samples which do not lie on the correlation line (Fig. 3) had the $\mathrm{MgO}$ and $\mathrm{CaO}$ contents of 2.7 and $17.9 \%$ and 6.3 and $16.6 \%$, respectively. They represent sandstones with calcite and patchy pyrite cement. While mixed carbonate and siltstone samples were formed during sedimentation, mixed dolomitic sandstone, in some cases also dolomitic coarsegrained siltstone, are in this group based on diagenetic influences. The carbonate content of mixed rocks was 30-50\% (Fig. 6d). Cement consists of cloudy finecrystalline or medium- to coarse-crystalline clear dolomite. Rare fine interlayers with calcite cement were observed. Patchy distribution of cement was common, which is often associated with pyrite. Detrital grains and crystals of pyrite were often coated with carbonate rims (Fig. 6d). This indicates that pyrite has formed earlier than carbonate. In rare cases calcite occurred as clear medium- to coarsecrystalline grains.

\section{Mineralogical composition}

Bulk mineralogical qualitative XRD analysis showed that dolostones were comprised mainly of dolomite and IR including quartz and K-feldspar (Fig. 7a) and very small amounts of illite, illite-smectite, chlorite, and kaolinite. Dolomitic marlstones are composed of the same minerals as dolostones. In some samples hematite was also recorded. Mixed carbonate-siliciclastic rocks consist of quartz, dolomite, illite, chlorite, and K-feldspar (Fig. 7b). Siliciclastic rocks consist of quartz, K-feldspar, dolomite, illite, and chlorite (Fig. 7c). Mineralogical XRD analysis of a bulk sample can only determine the main components in the rock; occasionally an admixture of iron-bearing minerals is also recorded. The XRD mineralogical analysis of the clay fraction $(<0.005 \mathrm{~mm})$ is more efficient for identifying the iron-bearing minerals (Table 2, Fig. 8a), since most of them occur in the clay fraction of the rocks. The clay fraction of dolostones and dolomitic marlstones which formed $0.8-60.1 \%$ of the rock in 22 samples, mainly consists of illite, chlorite, K-feldspar, and quartz, with an admixture of goethite, hematite, and siderite. The clay fraction of siliciclastic rocks, forming $0.3-69 \%$ of the rock in 59 samples, mainly consists of illite, chlorite, kaolinite, montmorillonite-chlorite, feldspar, quartz and smaller amounts of hematite, goethite, and siderite (Table 2). The clay fraction content was higher in carbonate rocks than in siliciclastic rocks, but average illite, chlorite, montmorillonite, and siderite contents were similar. The kaolinite, goethite, and hematite contents were higher in siliciclastic rocks, while the quartz and feldspar contents were higher in the clay fraction of carbonate rocks (Fig. 8a). 

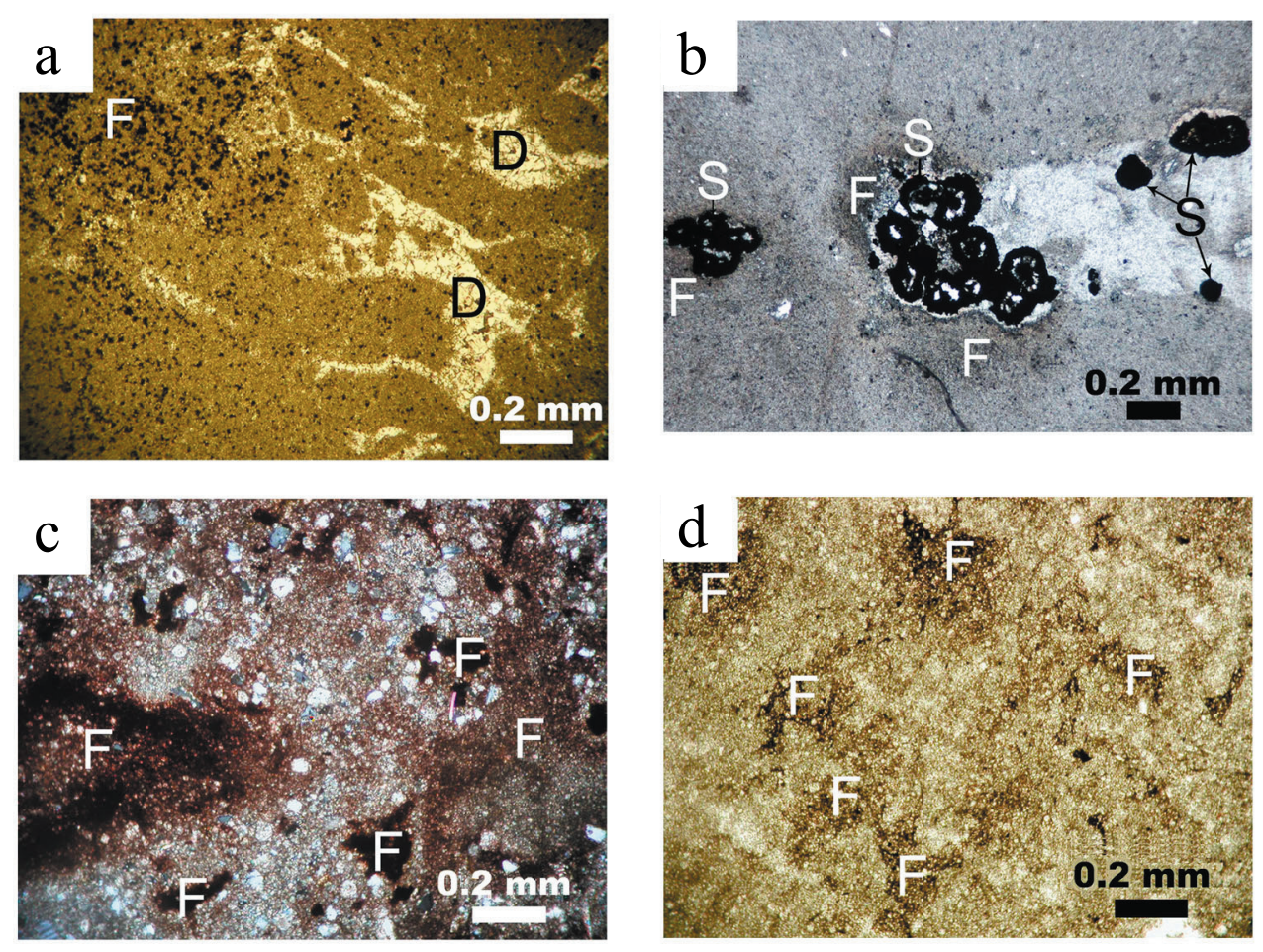

Fig. 5. Thin sections of dolostones and dolomitic marlstones. (a) Aphanocrystalline cloudy dolostone penetrated by vugs and fractures filled with authigenic transparent dolomite (D). Abundant fine goethite (hematite) grains and pyrite crystals $(5-15 \mu \mathrm{m})$ are scattered in the matrix. Concentrations of goethite (hematite) grains occur in places (F). Mehikoorma (421) core, $190.6 \mathrm{~m}$, plane-polarized light. $\mathrm{MgO}$ content $18.5 \%$, IR content $8.9 \%, \mathrm{Fe}_{2} \mathrm{O}_{3 \text { total }}$ content $1.63 \%, \mathrm{Fe}_{2} \mathrm{O}_{3 \text { total }} / \mathrm{Al}_{2} \mathrm{O}_{3}$ ratio 1.78 . For mineralogical analysis see Fig. 7a. (b) Aphanocrystalline semitransparent dolostone $(<0.004 \mathrm{~mm})$. Abundant Fe-hydroxide (F) grains $(0.005-0.01 \mathrm{~mm})$ and pigmented spots with irregular boundaries $(0.01-0.02 \mathrm{~mm})$ dispersed in the dolomite matrix. The rock is penetrated by wavy lense-shaped planes connected with vugs and in some places by aggregates of authigenic concentric crystals of sphalerite (S) (0.1-0.2 mm). Häädemeeste core, $79.0 \mathrm{~m}$, Narva Stage, Vadja Formation. Planepolarized light. $\mathrm{MgO}$ content $19.5 \%$, IR content $3.34 \%$, total iron content $1.73 \%, \mathrm{Fe}_{2} \mathrm{O}_{3 \text { total }} / \mathrm{Al}_{2} \mathrm{O}_{3}$ ratio 3.15 . (c) Very finely to finely crystalline silty dolomitic marlstone, patchily pigmented by Feoxides (F). Pigmentation is strong in places, and irregular opaque patches of hematite/goethite occur. Mehikoorma (421) core, $161.2 \mathrm{~m}$, plane-polarized light. $\mathrm{MgO}$ content $18.5 \%$, IR content $10.8 \%$, total iron content $3.91 \%, \mathrm{Fe}_{2} \mathrm{O}_{3 \text { total }} / \mathrm{Al}_{2} \mathrm{O}_{3}$ ratio 0.54 . (d) Cloudy very finely crystalline dolomitic marl, patchily pigmented by Fe-hydroxides (F). Taagepera core, $175 \mathrm{~m}$, plane-polarized light. $\mathrm{MgO}$ content $11.3 \%$, IR content $41.2 \%$, total iron content $5.52 \%, \mathrm{Fe}_{2} \mathrm{O}_{3 \text { total }} / \mathrm{Al}_{2} \mathrm{O}_{3}$ ratio 0.46 . 

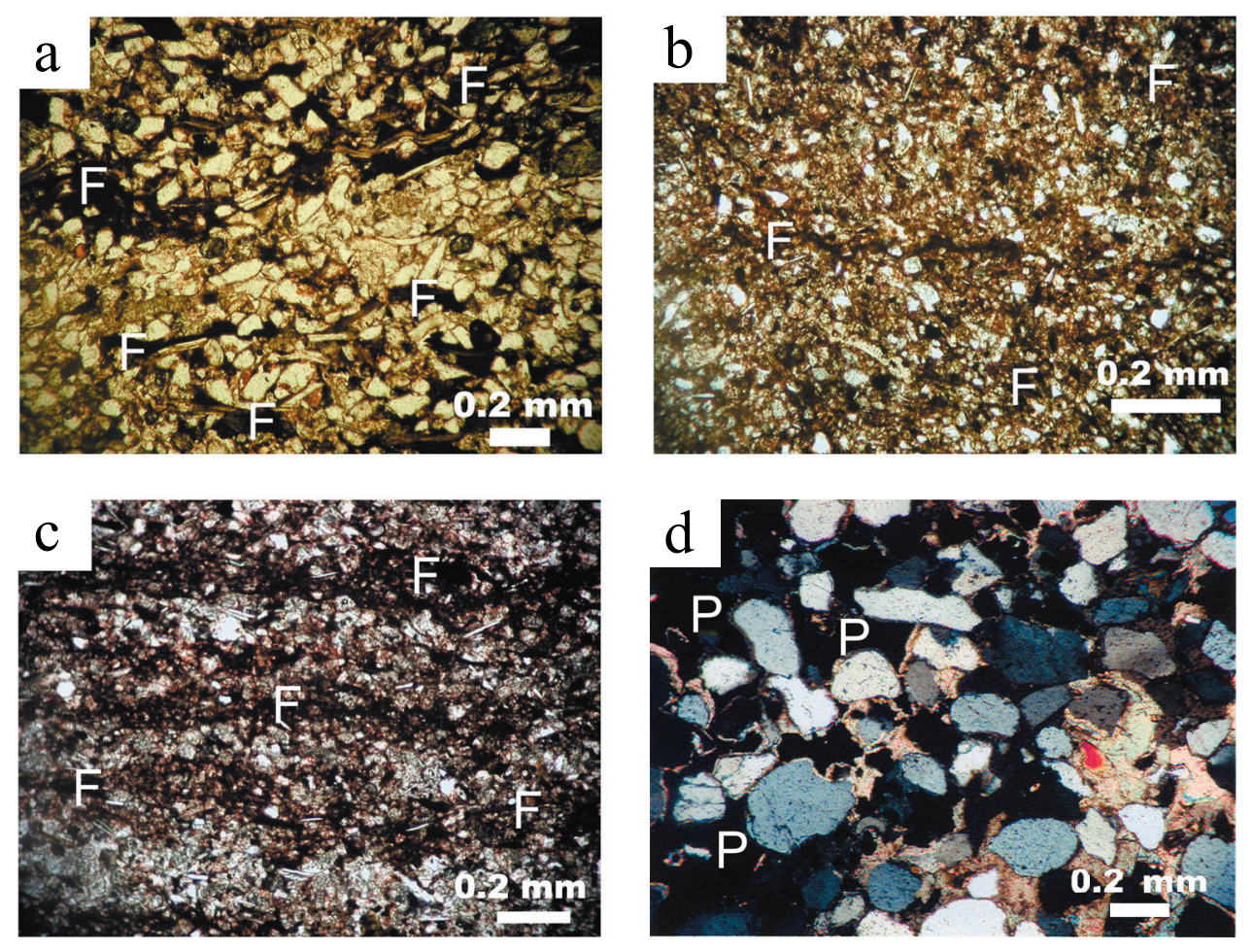

Fig. 6. Thin sections of siliciclastic and mixed carbonate-siliciclastic rocks. (a) Very fine-grained wavy-bedded sandstone. Argillaceous dolomite is pigmented by Fe-oxides (F). Strong pigmentation occurs along bedding surfaces. Valga (10) core, $118.5 \mathrm{~m}$, plane-polarized light. IR content is $93 \%$, of which clay minerals form about $10 \%$. Among detrital part quartz dominates (80\%), feldspars and micas form both about $10 \%$. Total iron content $2.94 \%, \mathrm{Fe}_{2} \mathrm{O}_{3 \text { total }} / \mathrm{Al}_{2} \mathrm{O}_{3}$ ratio 0.32. (b) Siltstone, indistinctly wavy-bedded, with patchy goethite/hematite pigmentation (F). Tartu (453) core, $46.0 \mathrm{~m}$, crossed polars. IR content is $72.4 \%$, of which clay minerals form about $40 \%$. Among detrital grains quartz forms about $70 \%$, feldspars form $20-25 \%$, and micas 5-10\%. Total iron content $6.47 \%$, $\mathrm{Fe}_{2} \mathrm{O}_{3 \text { total }} / \mathrm{Al}_{2} \mathrm{O}_{3}$ ratio 0.49 . (c) Mixed dolomite-siliciclastic rock: wavy-bedded silty dolomitic marlstone. Strong hematite-pigmentation $(\mathrm{F})$ alternating with less pigmented beds $(0.2-0.9 \mathrm{~mm})$. Mehikoorma (421) core, $154.6 \mathrm{~m}$, plane-polarized light. IR content is $53.2 \%$, of which clay minerals constitute about $35 \%$. Among detrital minerals quartz makes up approximately $70 \%$, feldspars and micas account both for $15 \%$. Total iron content $3.21 \%, \mathrm{Fe}_{2} \mathrm{O}_{3 \text { total }} / \mathrm{Al}_{2} \mathrm{O}_{3}$ ratio 0.39 . (d) Fine- to medium-grained cement-supported sandstone with clear calcite cement. Patchy cement is represented by pyrite (P), whose crystals are surrounded by calcite rims. Värska (6) core, $293.0 \mathrm{~m}$, crossed polars. IR content is $64.1 \%$, of which clay minerals constitute about $5 \%$. Among detrital minerals quartz dominates, making up $85-90 \%$ of the rock. Feldspars make up the remaining $10-15 \%$. Total iron content $2.3 \%, \mathrm{Fe}_{2} \mathrm{O}_{3 \text { total }} / \mathrm{Al}_{2} \mathrm{O}_{3}$ ratio 1.03 . 

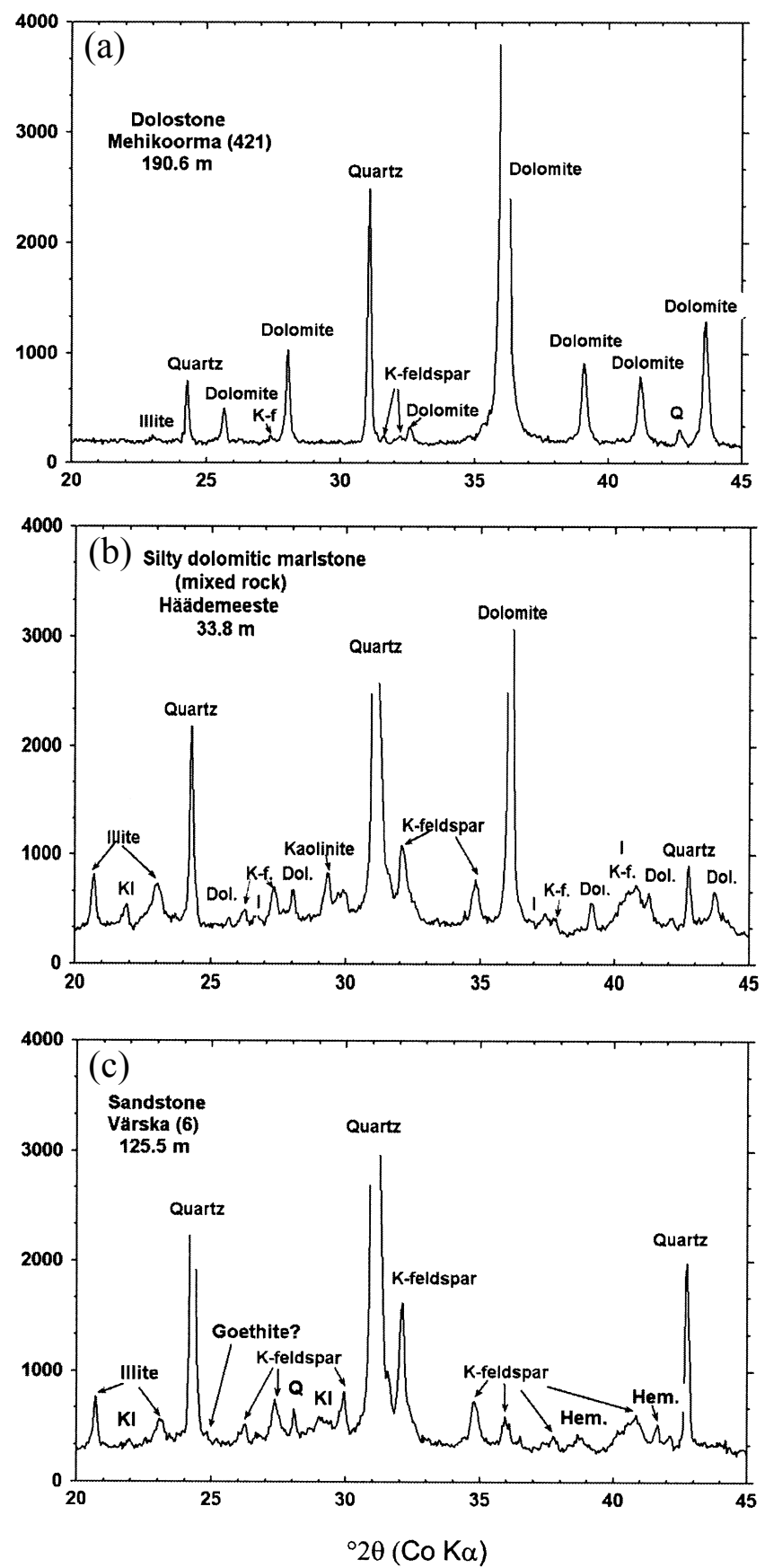

Fig. 7. Bulk mineralogical composition of (a) dolostone of the Mehikoorma (421) core, $190.6 \mathrm{~m}$, (b) silty dolomitic marlstone (mixed rock) of the Häädemeeste core, $33.8 \mathrm{~m}$, and (c) sandstone of the Värska (6) core, 125.5 m. XRD analysis by T. Kallaste. Q, quartz; K-f., K-feldspar; K1, kaolinite; I, illite; Dol., dolomite; Hem., hematite. 
Table 2. Mineralogical composition of the clay fraction $(<0.005 \mathrm{~mm})$ of the rocks of the Mehikoorma (421), Ruhnu (500), and Võru cores, determined by XRD analysis

\begin{tabular}{|c|c|c|c|c|c|c|c|c|c|c|c|c|c|c|}
\hline \multirow[b]{2}{*}{ 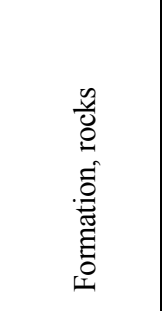 } & \multirow[b]{2}{*}{ 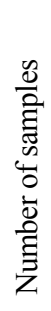 } & \multirow[b]{2}{*}{ 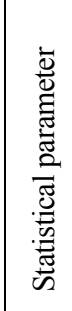 } & \multirow[b]{2}{*}{ 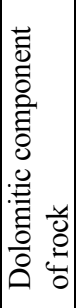 } & \multirow[b]{2}{*}{ 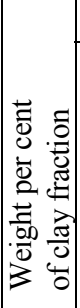 } & \multicolumn{5}{|c|}{ Clay component, $\%$} & \multicolumn{5}{|c|}{ Other minerals, $\%$} \\
\hline & & & & & 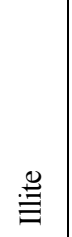 & $\frac{\stackrel{0}{0}}{\frac{0}{0}}$ & 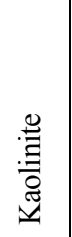 & 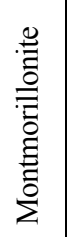 & 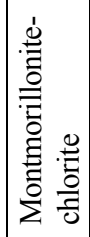 & 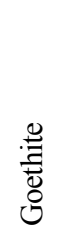 & 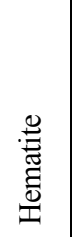 & 胥 & 营 & \\
\hline \multirow{3}{*}{$\begin{array}{l}\text { Aruküla, } \\
\text { Kernave, } \\
\text { siliciclastic }\end{array}$} & 19 & & 0 & 1.4 & 52 & 0 & 0 & 0 & & 0 & 0 & 0 & 0 & 0 \\
\hline & & Max & 30.8 & 69 & 93 & 46 & 25 & 5 & ( & 10 & 15 & 5 & 5 & 4 \\
\hline & & Avg & 6.3 & 21.3 & 81.5 & 14.3 & 3.8 & 0. & ( & 0.8 & 1.9 & 0 & & 0.5 \\
\hline \multirow{3}{*}{$\begin{array}{l}\text { Leivu, } \\
\text { siliciclastic }\end{array}$} & 9 & Min & 0 & 1 & 55 & 18 & 0 & 0 & 0 & 0 & 0 & 0 & 0 & 0 \\
\hline & & Max & 37.1 & 54.1 & 8 & 4 & 0 & 7 & & & tha & & ( & 7 \\
\hline & & Avg & 20.2 & 10.7 & 71 & 26.2 & 0 & 0 & & 0 & 1.3 & & ( & 1.8 \\
\hline \multirow{3}{*}{$\begin{array}{l}\text { Leivu, } \\
\text { Vadja, } \\
\text { carbonate }\end{array}$} & 18 & Min & 3 & 0.8 & 48 & 10 & 0 & 0 & ( & 0 & 0 & 0 & 0 & 0 \\
\hline & & Max & 72.9 & 60.1 & 88 & 42 & 0 & 10 & 23 & 5 & 10 & 10 & & 5 \\
\hline & & Avg & 36 & 36 & 69.7 & 22.9 & 0 & 1.6 & & 0.3 & 1.4 & 3.8 & & 1.2 \\
\hline \multirow{3}{*}{$\begin{array}{l}\text { Pärnu, } \\
\text { Rezekne, } \\
\text { siliciclastic }\end{array}$} & 31 & Min & 0 & 0.3 & 15 & 0 & 0 & 0 & & 0 & 0 & 0 & 0 & 0 \\
\hline & & Max & 38.2 & 37 & 99.8 & 37 & 10 & 5 & oJ & 5 & 10 & 20 & 30 & 5 \\
\hline & & Avg & 7.6 & 7.1 & 74.7 & 13.3 & 1.7 & 0.5 & & 0.5 & 0.6 & & 2.7 & 0.4 \\
\hline \multirow{3}{*}{$\begin{array}{l}\text { Pärnu, } \\
\text { Rezekne, } \\
\text { carbonate }\end{array}$} & 4 & Min & 25.2 & 15.5 & 75 & 15 & 0 & 0 & 0 & 0 & 0 & 5 & 5 & 0 \\
\hline & & Max & 75 & 43 & 85 & 25 & 0 & 0 & ( & 0 & 0 & 20 & 30 & 1.5 \\
\hline & & Avg & 45.5 & 25.1 & 80 & 20 & 0 & 0 & 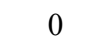 & 0 & 0 & 11.3 & 20 & 0.4 \\
\hline \multirow{3}{*}{$\begin{array}{l}\text { Total } \\
\text { samples }\end{array}$} & 81 & Min & 0 & 0.3 & 15 & 0 & 0 & 0 & 0 & 0 & 0 & 0 & 0 & 0 \\
\hline & & Max & 75 & 69 & 99.8 & 46 & 25 & 10 & 85 & 10 & 15 & 20 & 30 & 5 \\
\hline & & Avg & 23.9 & 22.4 & 76.2 & 18 & 1.3 & 0.6 & & 0.4 & 1 & 4.8 & 6 & 0.6 \\
\hline
\end{tabular}

The mineralogical composition of the heavy fraction was studied in 131 samples from four boreholes (Table 3, Fig. 8b). The heavy fraction accounted for 0-6.7\% of siliciclastic (average $0.7 \%$ ) and $0-64.1 \%$ of carbonate rocks (average $8.3 \%$ ). The heavy fraction of carbonate rocks consisted of goethite and hematite (average $30.4 \%)$, transparent heavy minerals $(22.9 \%)$, ilmenite and magnetite $(21.6 \%)$, pyrite $(14.1 \%)$, biotite $(4.8 \%)$, muscovite $(2.1 \%)$, barytes $(1.8 \%)$, leucoxene $(1.7 \%)$, and chlorite $(0.6 \%)$ (Table 3, Fig. 8 b). The heavy fraction of siliciclastic rocks included transparent heavy minerals (average $33.1 \%)$, biotite $(22.1 \%)$, ilmenite and magnetite (19.9\%), muscovite (4.2\%), goethite and hematite $(8.4 \%)$, leucoxene $(5.4 \%)$, pyrite $(3.2 \%)$, chlorite $(1.8 \%)$, and barytes $(1.7 \%)$. The biotite, chlorite, muscovite, and leucoxene contents were higher in the heavy fraction of siliciclastic rocks, while pyrite, goethite, and hematite showed higher values in carbonate rocks. The barite content was approximately the same, but the average ilmenite and 
(a)

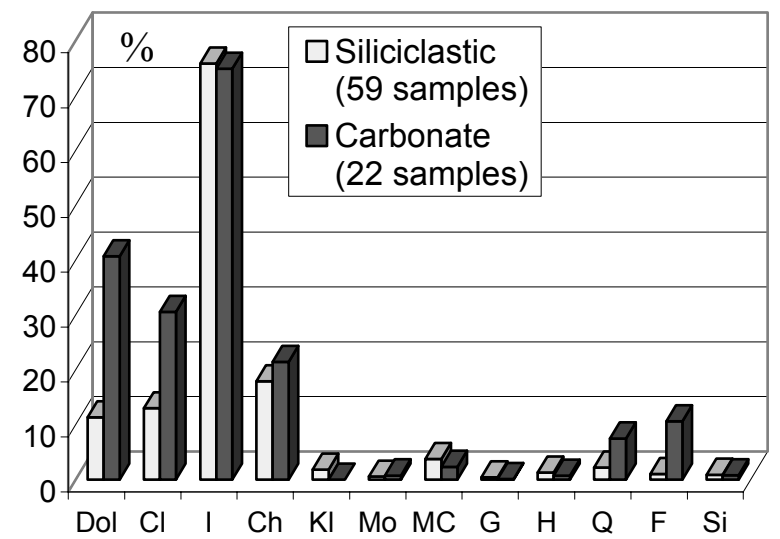

(b)

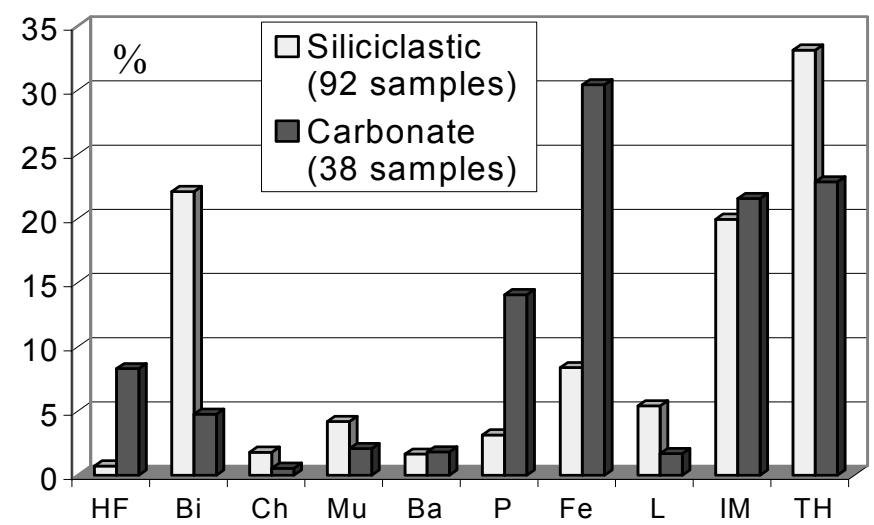

Fig. 8. Average mineral composition (in per cent) of carbonate and siliciclastic rocks in (a) clay fraction (Table 2) and (b) heavy fraction (Table 3). Dol, dolomite component; Cl, clay fraction; I, illite; Ch, chlorite; Kl, kaolinite; Mo, montmorillonite; MC, montmorillonite-chlorite; G, goethite; $\mathrm{H}$, hematite; Q, quartz; F, feldspar; Si, siderite; HF, heavy fraction; Bi, biotite; Mu, muscovite; $\mathrm{Ba}$, barytes; P, pyrite; Fe, Fe-oxides; L, leucoxene; IM, ilmenite and magnetite; TH, transparent heavy minerals.

magnetite content was higher in carbonate rocks (Fig. 8b). Magnetite occurred more often in carbonate rocks, while ilmenite prevailed in siliciclastic rocks. Sometimes sulphides (pyrite and sphalerite) were recorded in the thin sections of dolostones (Fig. 5a,b) and dolomitic marlstones. Some siliciclastic samples included $1-2 \%$ goethite and hematite (Fig. 6a,b). Hematite, goethite, and pyrite could be identified in some thin sections of mixed carbonate-siliciclastic rocks (Fig. 6c,d). 
Table 3. Heavy mineral fraction $(0.05-0.1 \mathrm{~mm})$ of the rocks of the Mehikoorma (421), Ruhnu (500), Tartu (453), and Valga (10) cores, determined by immersion mineralogical analysis

\begin{tabular}{|c|c|c|c|c|c|c|c|c|c|c|c|c|}
\hline \multirow[b]{2}{*}{ 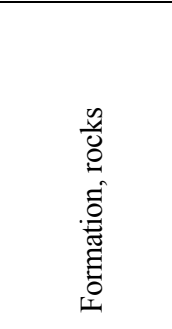 } & \multirow[b]{2}{*}{ 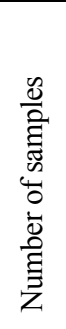 } & \multirow[b]{2}{*}{ 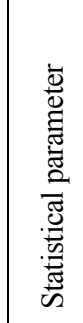 } & \multirow[b]{2}{*}{ 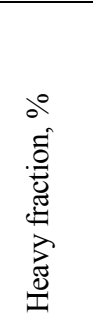 } & \multicolumn{9}{|c|}{ Mineral component, $\%$} \\
\hline & & & & . & $\frac{\stackrel{0}{0}}{\frac{0}{0}}$ & 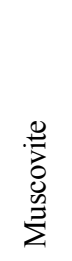 & 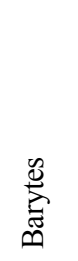 & 莹 & 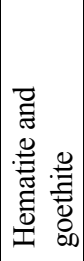 & 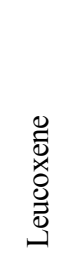 & 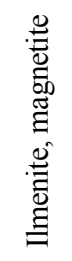 & 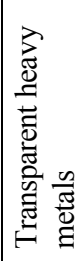 \\
\hline \multirow{3}{*}{$\begin{array}{l}\text { Aruküla, } \\
\text { Kernave, } \\
\text { siliciclastic }\end{array}$} & 51 & Min & 0 & 0 & 0 & 0 & 0 & 0 & 0 & 0.6 & 0.8 & 2.4 \\
\hline & & Max & 1.6 & 93.2 & 15.5 & 57.2 & 8.6 & 3.6 & 62.0 & 29.6 & 67.2 & 46.9 \\
\hline & & Avg & 0.4 & 22.7 & 1.5 & 4.2 & 0.3 & 0.5 & 7.2 & 8.9 & 29.0 & 25.7 \\
\hline \multirow{3}{*}{$\begin{array}{l}\text { Kernave, } \\
\text { carbonate }\end{array}$} & 2 & Min & 0.4 & 1.0 & 0 & 0.2 & 0 & 0.2 & 3.4 & 0.8 & 0.6 & 0.1 \\
\hline & & Max & 32.6 & 1.5 & 0.1 & 2.0 & 0 & 0.6 & 94.6 & 5.4 & 50.2 & 39.6 \\
\hline & & Avg & 16.52 & 1.2 & 0 & 1.1 & 0 & 0.4 & 49.0 & 3.1 & 25.4 & 19.8 \\
\hline \multirow{3}{*}{$\begin{array}{l}\text { Leivu, } \\
\text { siliciclastic }\end{array}$} & 11 & Min & 0 & 4.6 & 0 & 0.8 & 0 & 0 & 0.2 & 0.2 & 3.0 & 1.8 \\
\hline & & Max & 2.9 & 73.0 & 6.8 & 16.0 & 30 & 7.2 & 51.4 & 13.0 & 20.8 & 34.2 \\
\hline & & Avg & 0.5 & 38.3 & 2.7 & 7.4 & 4.4 & 2.1 & 11.3 & 5.0 & 11.1 & 17.1 \\
\hline \multirow{3}{*}{$\begin{array}{l}\text { Leivu, } \\
\text { Vadja, } \\
\text { carbonate }\end{array}$} & 28 & Min & 0.2 & 0 & 0 & 0 & 0 & 0 & 0.6 & 0 & 0.4 & 0.2 \\
\hline & & Max & 64.1 & 34.7 & 3.6 & 22.0 & 41.2 & 91.0 & 87.8 & 3.8 & 78.6 & 61.0 \\
\hline & & Avg & 6.5 & 8.3 & 0.4 & 3.2 & 5.4 & 23.3 & 32.9 & 0.8 & 15.3 & 9.9 \\
\hline \multirow{3}{*}{$\begin{array}{l}\text { Pärnu, } \\
\text { Rezekne, } \\
\text { siliciclastic }\end{array}$} & 30 & Min & 0 & 0 & 0 & 0 & 0 & 0 & 0.4 & 0 & 1.8 & 4.2 \\
\hline & & Max & 6.7 & 53.0 & 7.2 & 12.7 & 2.7 & 85.6 & 25.1 & 5.7 & 42.6 & 86.4 \\
\hline & & Avg & 1.3 & 5.3 & 1.2 & 1.0 & 0.3 & 6.8 & 6.6 & 2.4 & 19.8 & 56.6 \\
\hline \multirow{3}{*}{$\begin{array}{l}\text { Pärnu, } \\
\text { Rezekne, } \\
\text { carbonate }\end{array}$} & 9 & Min & 0.4 & 0.1 & 0 & 0 & 0 & 0 & 0.4 & 0.2 & 4.2 & 1.1 \\
\hline & & Max & 6.1 & 33.0 & 3.6 & 16.2 & 0.4 & 40.1 & 45.3 & 2.4 & 91.6 & 73.4 \\
\hline & & Avg & 2.0 & 4.8 & 1.2 & 2.0 & 0.1 & 18.5 & 9.4 & 1.2 & 24.0 & 38.9 \\
\hline \multirow{3}{*}{$\begin{array}{l}\text { Total } \\
\text { samples }\end{array}$} & 131 & Min & 0 & 0 & 0 & 0 & 0 & 0 & 0 & 0 & 0.4 & 0.1 \\
\hline & & Max & 64.1 & 93.2 & 15.5 & 57.2 & 41.2 & 91.0 & 94.6 & 29.6 & 91.6 & 86.4 \\
\hline & & Avg & 4.5 & 13.4 & 1.2 & 3.1 & 1.7 & 8.6 & 19.4 & 3.6 & 20.7 & 28.0 \\
\hline
\end{tabular}

\section{INTERPRETATION AND DISCUSSION}

Primary variation in the total iron content of Palaeozoic sedimentary rocks has been explained by different influx of detrital grains and various weathering and erosion during transgressive and regressive sea-level changes and climate changes (Ellwood et al. 2000, 2001). During diagenesis the total iron content of sediments could increase, decrease or iron could change its valence (Elmore 1993; Brand 1994; Mücke 1994; Shogenova 1999; Vigliotti et al. 1999; Yamazaki et al. 2003; Funk et al. 2004; Zwing et al. 2005). These processes are mainly controlled by redox potentials of diagenetic fluids. Iron oxides dissolve in suboxic and anoxic (sulphate-reducing) environments, but precipitate in oxidation conditions (Passier et al. 2001). 
The $\mathrm{Fe}_{2} \mathrm{O}_{3 \text { total }} / \mathrm{Al}_{2} \mathrm{O}_{3}$ ratio can serve as an indicator of detrital input of iron minerals versus diagenetic input. In this case Clark values of iron and aluminium and their relation in the specific rock type (Turekian \& Wedepohl 1961) is used for calculating the excess of the element detrital level (Thomson et al. 1995). The $\mathrm{Fe} / \mathrm{Al}_{\text {detrital }}$ ratios for a global survey of carbonates by Turekian \& Wedepohl (1961), which have been recalculated into oxides $\left(\mathrm{Fe}_{2} \mathrm{O}_{3 \text { total }} / \mathrm{Al}_{2} \mathrm{O}_{3 \text { detrital }}\right)$, are 0.68 for carbonates and 0.3 for sandstones. These values coincide with the average values of the $\mathrm{Fe}_{2} \mathrm{O}_{3 \text { total }} / \mathrm{Al}_{2} \mathrm{O}_{3}$ ratio which we got for our Devonian dolostones and siliciclastic rocks (Table 1). Larger values reflect diagenetic mineralization, while smaller values than the $\mathrm{Fe}_{2} \mathrm{O}_{3 \text { total }} / \mathrm{Al}_{2} \mathrm{O}_{3 \text { detrital }}$ ratio are the result of diagenetic corrosion and dissolution. In the investigated Devonian rocks the total iron content is not very high and mainly correlates with the clay content (Fig. 4a-c). However, the $\mathrm{Fe}_{2} \mathrm{O}_{3 \text { total }} / \mathrm{Al}_{2} \mathrm{O}_{3}$ ratio shows the available excess of iron over detrital input in some carbonate samples, mainly from the Vadja Formation (Fig. 2, Table 1). The highest $\mathrm{Fe}_{2} \mathrm{O}_{3 \text { total }} / \mathrm{Al}_{2} \mathrm{O}_{3}$ ratio was obtained for dolostones of the Mehikoorma (421) (Fig. 5a) and Häädemeeste cores (Fig. 5b). Iron minerals in these rock samples, represented by Fe-oxides (hematite and goethite) and Fesulphides (pyrite and sphalerite), are obviously of diagenetic origin and could have formed in an oxidizing environment. In the other carbonate samples the $\mathrm{Fe}_{2} \mathrm{O}_{3 \text { total }} /$ $\mathrm{Al}_{2} \mathrm{O}_{3}$ ratio is lower than the $\mathrm{Fe}_{2} \mathrm{O}_{3 \text { total }} / \mathrm{Al}_{2} \mathrm{O}_{3 \text { detrital }}$ ratio, which could be indicative of a reducing environment. Significant correlation of $\mathrm{Fe}_{2} \mathrm{O}_{3 \text { total }}$ with the $\mathrm{Al}_{2} \mathrm{O}_{3}$ content for all rock types suggests prevailingly primary accumulation of ironbearing minerals and possible changes in their form during diagenesis. Variations from the $\mathrm{Fe}_{2} \mathrm{O}_{3 \text { total }} / \mathrm{Al}_{2} \mathrm{O}_{3 \text { detrital }}$ ratios of 0.68 and 0.3 indicate diagenetic increase and decrease in the total iron content also in siliciclastic rocks.

As stated above, the total iron contents of red, pink, mottled, and grey rocks are similar. Such a range of the total iron content is in agreement with data from other "red beds" (Mücke 1994) and also proves that the colour of the rocks does not depend on the iron content, but is mainly determined by its form. Red coloration is mainly determined by hematite or, in other words, by excess ferric iron, in which $\mathrm{Fe}_{2} \mathrm{O}_{3} / \mathrm{FeO}$ ratios $>2$ (Turner 1980). The formation of hematite can be explained by frequently changing redox conditions during diagenesis. A low water table and absence of organic matter are favourable for an oxidizing environment and formation of hematite during early diagenesis (Van Houten 1973). The FeO content of Estonian Devonian rocks is rather low - in a range of $0.03-0.43 \%$ in carbonate, $0.05-0.52 \%$ in siliciclastic, and $0.01-0.94 \%$ in mixed rocks. The average $\mathrm{FeO}$ content values in all rocks are between 0.16 and $0.24 \%$, being the highest in marlstones and mixed rocks. In the Mehikoorma (421) core the $\mathrm{Fe}_{2} \mathrm{O}_{3} / \mathrm{FeO}$ ratio is rather high (Fig. 2), remaining below 2 only in a few sandstones. The highest ratio was observed in the mainly mottled and red rocks of $\mathrm{D}_{2} \mathrm{nr} K-\mathrm{D}_{2}$ artr, while the mainly grey succession of $\mathrm{D}_{1} \mathrm{rz}-\mathrm{D}_{2} \mathrm{nr} V$ revealed a lower total iron content and a smaller $\mathrm{Fe}_{2} \mathrm{O}_{3} / \mathrm{FeO}$ ratio. It should be noted that such a low $\mathrm{FeO}$ content as in the Devonian has been recorded only in limestones and 
argillaceous limestones of the Estonian Ordovician and Silurian sequences, but the average total iron content of the latter rocks is significantly lower $(0.3-1.1 \%$; Shogenova 1999). Ordovician-Silurian marlstones, dolomitic marlstones, and dolostones of different genesis have an average $\mathrm{FeO}$ content in the range of $0.29-1.02 \%$ and $\mathrm{Fe}_{2} \mathrm{O}_{3 \text { total }}$ in the range of $0.64-2.96 \%$, with the highest values in glauconitebearing carbonate rocks and secondary dolostones (Shogenova 1999). The average total iron content of the studied Devonian carbonates is $1.56-2.52 \%$, indicating excess $\mathrm{Fe}_{2} \mathrm{O}_{3}$ in Devonian rocks in comparison with the other Palaeozoic rocks. The occurrence of $\mathrm{Fe}$ (III) may be evidence of a prevailing oxidizing environment during early diagenesis.

The studied carbonate rocks have a higher $\mathrm{Fe}_{2} \mathrm{O}_{3 \text { total }} / \mathrm{Al}_{2} \mathrm{O}_{3}$ ratio than siliciclastic rocks, while the siliciclastics have higher $\mathrm{TiO}_{2} / \mathrm{Al}_{2} \mathrm{O}_{3}$ and $\mathrm{K} 2 \mathrm{O} / \mathrm{Al}_{2} \mathrm{O}_{3}$ ratios (Table 1, Fig. 4a-c). According to Turekian \& Wedepohl (1961), the global average values of the last two ratios are also higher in carbonate rocks than in sandstones. Our results of chemical analysis of the Devonian rocks are explained by (1) higher average goethite, hematite, magnetite, and pyrite contents in heavy fractions of carbonate rocks (Fig. 8b), (2) higher contents of leucoxene and ilmenite in siliciclastic rocks (Fig. 8b), and (3) transformation of minerals from the clay fraction into hematite during early diagenesis preceding dolomitization. The presence of pyrite, sphalerite, and siderite (in small amounts) in carbonate rocks is also supported by the absence of $\mathrm{Fe}_{2} \mathrm{O}_{3 \text { total }}-\mathrm{FeO}$ correlation in carbonate rocks (Fig. 4e). In contrast, the $\mathrm{FeO}$ content in a part of mixed and siliciclastic rocks correlates with the $\mathrm{Fe}_{2} \mathrm{O}_{3 \text { total }}$ content. This can be explained by the occurrence of $\mathrm{Fe}(\mathrm{II})$ in the clay fraction of mixed carbonate-siliciclastic and siliciclastic rocks. In the other samples $\mathrm{FeO}$ correlates with the $\mathrm{TiO}_{2}$ content, indicating the occurrence of ilmenite in the heavy fraction. Some samples located lower on the $\mathrm{Fe}_{2} \mathrm{O}_{3 \text { total }}-\mathrm{FeO}$ plot than the correlated group (their $\mathrm{Fe}_{2} \mathrm{O}_{3 \text { total }} / \mathrm{FeO}$ proportion is higher than in other rocks) may also include pyrite and sphalerite in the heavy fraction. The negative correlation of the total iron content with the $\mathrm{MgO}$ content in carbonate rocks and the absence of any correlation between these parameters in siliciclastic rocks (Fig. 4d) suggests a decrease in the content of iron minerals during dolomitization of carbonate rocks and redistribution of iron minerals during dolomite cementation of siliciclastic rocks (Fig. 9). The first explanation could not be checked using comparison of Devonian limestones with dolostones due to complete dolomitization of the studied carbonate rocks. However, comparison of the Devonian dolostones with a total Fe content of $0.63-3.3 \%$ in the Mehikoorma (421) core with the underlying Upper Ordovician limestones shows a lower range of the total iron content for limestones (0.86-2.23\%) (Shogenova et al. 2005). However, the Ordovician limestones have a higher average $(1.76 \%)$ than the Devonian dolostones (1.56\%). This also supports the conclusion about the general decrease in the total iron content of Devonian dolostones with a few cases of authigenic secondary mineralization where the $\mathrm{Fe}_{2} \mathrm{O}_{3 \text { total }} / \mathrm{Al}_{2} \mathrm{O}_{3}$ ratio is higher than the $\mathrm{Fe}_{2} \mathrm{O}_{3 \text { total }} / \mathrm{Al}_{2} \mathrm{O}_{3 \text { detrital }}$ ratio. 


\begin{tabular}{|l|c|c|}
\hline \multicolumn{1}{|c|}{ Process } & Primary & \multicolumn{2}{c|}{ Diagenesis } \\
\cline { 3 - 4 } & deposition & Early Middle Late \\
\hline Accumulation of ilmenite & & \\
\hline Formation of leucoxene & & \\
\hline Formation of authigenic anatase & & \\
\hline Accumulation of magnetite & & \\
\hline Oxidation of magnetite & & \\
\hline Formation of iron oxides & & \\
\hline Formation of patchy distribution of iron oxides & & \\
\hline Formation of iron oxide coatings & & \\
\hline Formation of pyrite & & \\
\hline Formation of siderite, sphalerite & & \\
\hline Formation of dolomite & & \\
\hline Formation of dolomitic cement & & \\
\hline Formation of calcitic cement & & \\
\hline Chloritization of feldspars & & \\
\hline Corrosion of detrital partings & & \\
\hline
\end{tabular}

Fig. 9. Paragenesis of mineral formation and alteration.

Iron-bearing minerals have altered significantly during diagenetic processes (Fig. 9; Kleesment \& Paap 1978; Kleesment 1984, 1998). In early diagenesis dispersed fine grains and aggregates of pyrite precipitated in sediments as a result of the bacterial reduction process (Fig. 5a,b). Later, larger pyrite crystals formed in vugs, fractures, and sandstone matrix, prior to late diagenetic replacement of dolomite by calcite (Fig. 6d). The formation of mottled, patchily distributed iron oxides (Figs $5 \mathrm{c}, \mathrm{d} ; 6 \mathrm{a}-\mathrm{c}$ ) is presumably connected with the middle phase of diagenesis (Fig. 9). The red colouring of sandstones due to grain coatings may be of early diagenetic origin (Kuršs \& Stinkule 1972), but some goethite and hematite could also have formed in later diagenetic stages from magnetite. Goethite and hematite in carbonate rocks could be of primary and diagenetic origin. Primary iron-bearing minerals were formed during sedimentation processes and their content correlates with the clay content (Figs 4a, 9). Secondary iron minerals do not correlate with the clay content as they formed from clay minerals and redistribution of iron is associated with dolomitization. Dolostone samples with secondary iron minerals show a poor correlation on the $\mathrm{Fe}_{2} \mathrm{O}_{3 \text { total }}-\mathrm{Al}_{2} \mathrm{O}_{3}$ plot, and their $\mathrm{Fe}_{2} \mathrm{O}_{3 \text { total }} / \mathrm{Al}_{2} \mathrm{O}_{3}$ ratio is higher than the $\mathrm{Fe}_{2} \mathrm{O}_{3 \text { total }} / \mathrm{Al}_{2} \mathrm{O}_{3 \text { detrital }}$ ratio (Fig. 2). In contrast, some of the carbonate and siliciclastic samples show a low total iron content for a given $\mathrm{Al}_{2} \mathrm{O}_{3}$ content (Fig. 4a). This decrease in the iron content may 
be connected with diagenetic processes during which some iron minerals could have dissolved in a reducing environment. In general, the total iron content decreased during dolomitization of carbonate rocks, but its concentration does not change significantly in siliciclastic rocks. Devonian siliclastic rocks of Estonia have also a higher total iron content than Cambrian siliciclastics (Shogenova et al. 2001). Devonian dolostones have a similar, but on average lower total iron content than Upper Ordovician rocks and a significantly lower iron content than Middle Ordovician rocks, probably due to late-diagenetic origin of the (Middle) Ordovician dolostones of the Mehikoorma (421) core (Shogenova et al. 2005).

\section{CONCLUSIONS}

(1) The IR of the Devonian carbonate rocks of Estonia consists mainly of illite, illite-smectite, chlorite, kaolinite, quartz, and K-feldspar, with minor hematite, goethite, pyrite, magnetite, and siderite. The IR of siliciclastic rocks includes mainly quartz, K-feldspar, illite, and chlorite, with minor Ti-bearing minerals, hematite, goethite, siderite, and pyrite.

(2) The total iron content of the rocks was controlled mainly by detrital input during the sedimentation process. Iron-bearing minerals changed their form during diagenesis and $\mathrm{Fe}(\mathrm{III})$ iron minerals became dominant due to an oxygenrich environment, low water table, and arid climate.

(3) Red coloration of siliciclastic rocks due to hematite coatings of quartz grains could be early diagenetic in origin, or could be also formed from magnetite and other iron oxides during later diagenetic stages. Red coloration of carbonate rocks (dolostones and marlstones) may by of early diagenetic origin before dolomitization, but iron pigmentation was redistributed also in the later diagenetic stages.

(4) The average values of the $\mathrm{Fe}_{2} \mathrm{O}_{3 \text { total }} / \mathrm{Al}_{2} \mathrm{O}_{3}$ ratio coincide with the $\mathrm{Fe} / \mathrm{Al}$ ratios in the sandstones and carbonates of the Earth's crust. The $\mathrm{TiO}_{2} / \mathrm{Al}_{2} \mathrm{O}_{3}$ and $\mathrm{K}_{2} \mathrm{O} / \mathrm{Al}_{2} \mathrm{O}_{3}$ ratios are higher in Devonian siliciclastic rocks of Estonia, but are higher in the carbonates of the Earth's crust (Turekian \& Wedepohl 1961).

(5) The iron oxides and hydroxides can be of primary, early diagenetic and/or late diagenetic (secondary) origin (Fig. 9). Detrital magnetite could have oxidized to hematite and goethite, while detrital ilmenite could transform to leucoxene during early diagenetic stages. Authigenic pyrite could have formed at all diagenetic stages. During dolomitization and dolomite cementation detrital iron minerals could be corroded and the total iron content could decrease from primary detrital values. Late diagenetic authigenic mineralization of sulphides associated with fractures and vugs took place in dolostones. Clay minerals could serve as a source of iron for authigenic mineralization leading to increase in total iron both in carbonate and siliciclastic rocks. 


\section{ACKNOWLEDGEMENTS}

This research was funded by the governmental target funding project No. $03320888 \mathrm{~s} 02$ from the Ministry of Science and Education of Estonia and supported by the Estonian Science Foundation (grants Nos 4157 and 5726). We are grateful to our colleagues from the Institute of Geology at Tallinn University of Technology: T. Linkova for wet chemical analysis, T. Kallaste for XRD analysis, Ü. Kestlane for preparation of thin sections, and G. Baranov for microphotographs of thin sections. The referees Prof. A. Hirt and Prof. E. Pirrus are thanked for the constructive reviews of the manuscript. We thank Prof. D. Tarling (Plymouth University) for improving the article structure and the English language.

\section{REFERENCES}

Abdalla, A., Puckette, J. \& Al-Shaieb, Z. 1997. Diagenetic banding: sealing mechanism in Simpson sandstone reservoirs in Central Oklahoma. In Simpson and Viola Groups in the Southern Midcontinent (Johnson, K. S., ed.), pp. 209-217. 1994 Symposium. Oklahoma Geological Survey, Circular 99.

Al-Juboury, A. I., Durovič, V. \& Durovičova, M. 1994. Heavy mineral association on the Carpathian Keuper rocks. Acta Geol. Univ. Comenianae, 50, 63-69.

Brand, U. 1994. Morphochemical and replacement diagenesis of biogenic carbonates. In Diagenesis, IV (Wolf, K. H. \& Chilingarian, G. V., eds), pp. 217-282. Elsevier, Amsterdam.

Dapples, E. C. 1979. Diagenesis of sandstones. In Diagenesis in Sediments and Sedimentary Rocks (Larson, G. \& Chilingar, G. V., eds), pp. 31-98. Elsevier, Amsterdam.

Ellwood, B. B., Crick, R. E., Hassani, A., Benoist, S. L. \& Young, R. H. 2000. Magnetosusceptibility event and cyclostratigraphy method applied to marine rocks: detrital input versus carbonate productivity. Geology, 28, 1135-1138.

Ellwood, B. B., Crick, R. E., Garcia-Alcalde Fernandez, J. L., Soto, F. M., Truyóls-Massoni, M., El Hassani, A. \& Kovas, E. J. 2001. Global correlation using magnetic susceptibility data from Lower Devonian rocks. Geology, 29, 583-586.

Elmore, R. D., London, D., Bagley, D. \& Fruit, D. 1993. Remagnetization by basinal fluids: testing the hypothesis in the Viola limestone, Southern Oklahoma. J. Geophys. Res., 98, 6237-6254.

Fairbridge, R. W. 1967. Phases of diagenesis and authigenesis. In Diagenesis in Sediments (Larsen, G. \& Chilingar, G. V., eds), pp. 19-89. Elsevier, Amsterdam.

Funk, J. A., von Dodeneck, T. \& Reitz, A. 2004. Integrated rock magnetic and geochemical quantification of redoxomorphic iron mineral diagenesis in Late Quaternary sediments from equatorial Atlantic. In The South Atlantic in the Late Quaternary: Reconstruction of Material Budgets and Current Systems (Wefer, G., Multitza, S. \& Ratmeyer, V., eds), pp. 237-260. Springer-Verlag, Berlin.

Haese, R. R., Petermann, H., Dittert, L. \& Schulz, H. D. 1998. The Early diagenesis of iron in pelagic sediments: a multidisciplinary approach. Earth Planet. Sci. Lett., 157, $233-248$.

Haubold, H. 1999. Alteration of magnetic properties of Palaeozoic platform carbonates during burial diagenesis (Lower Ordovician, Texas, USA). In Palaeomagnetism and Diagenesis in Sediments (Tarling, D. H. \& Turner, P., eds), Geol. Soc. London Spec. Publ., 151, 181-203.

Kleesment, A. 1984. The effect of secondary processes in the ratios of allothigenic minerals. Proc. Acad. Sci. Estonian SSR Geol., 33, 70-77 (in Russian). 
Kleesment, A. 1997. Devonian sedimentation basin. In Geology and Mineral Resources of Estonia (Raukas, A. \& Teedumäe, A., eds), pp. 205-208. Estonian Academy Publishers, Tallinn.

Kleesment, A. 1998. Authigenic overgrowths of detrital feldspar grains in the Devonian sequence of the East Baltic. Proc. Estonian Acad. Sci. Geol., 47, 229-241.

Kleesment, A. 2001. Devonian. In Valga (10) Drill Core (Põldvere, A., ed.), Estonian Geol. Sections, $3 ; 6-8,42-46$.

Kleesment, A. 2003. Devonian. In Ruhnu (500) Drill Core (Põldvere, A., ed.), Estonian Geol. Sections, 5, 12, Appendixes 7-12 on CD-ROM.

Kleesment, A. E. \& Paap, Ü. A. 1978. About postdepositional changes of garnet grains. Litol. polezn. iskopaemye, 5, 135-143 (in Russian).

Kleesment, A. \& Shogenova, A. 2005. Lithology and evolution of Devonian carbonate and carbonatecemented rocks in Estonia. Proc. Estonian Acad. Sci. Geol., 54, 153-180.

Kleesment, A. \& Valiukevičius, J. 1998. Devonian. In Tartu (453) Drill Core (Männik, P. ed.), Estonian Geol. Sections, 1, 17-18.

Kuršs, V. M. 1992. Devonskoe terrigennoe osadkonakoplenie na glavnom Devonskom pole. Zinatne, Riga (in Russian).

Kuršs, V. \& Stinkule, A. 1972. On the colour of the Giventian and lower Frasnian terrigenous sediments of the central Baltic region. In Regional'naya geologiya Pribaltiki i Belorussii (Ulst, R. G., ed.), pp. 59-67. Zinatne, Riga.

Larsen, G. \& Chilingar, G. V. 1979. Diagenesis in Sediments and Sedimentary Rocks. Elsevier, Amsterdam.

Lewchuk, M. T., Elmore, R. D. \& Evans, M. 2002. Remagnetization signature of Palaeozoic sedimentary rocks from the Patterson Creek Mountain anticline in West Virginia. Phys. Chem. Earth, 27, 1141-1150.

Love, L. G. 1971. Early diagenetic polyframboidal pyrite, primary and redeposited, from the Wenlockian Denbigh Grit Group, Conway, North Wales, U.K. J. Sedim. Petrol., 41, 1038 1044.

Marton, E. 1999. Diagenesis in platform carbonates: a palaeomagnetic study of a late Triassic-early Jurassic section, Tata (Hungary). In Palaeomagnetism and Diagenesis in Sediments (Tarling, D. H. \& Turner, P., eds), Geol. Soc. London Spec. Publ., 151, 157-166.

Mokrik, R. 2003. The Paleohydrogeology of the Baltic Basin. Vilnius University Press, Vilnius.

Morse, J. W. \& Mackenzie, F. T. 1990. Geochemistry of Sedimentary Carbonates. Elsevier, Amsterdam.

Mücke, A. 1994. Postdiagenetic ferruginization of sedimentary rocks (sandstones, oolitic ironstones, kaolins ans bauxites) - including a comparative study of the reddening of red beds. In Diagenesis, IV (Wolf, K. H. \& Chilingarian, G. V., eds), pp. 361-382. Elsevier, Amsterdam.

Narbutas, V. 1981. The importance of secondary changes in the lithogenesis of South Baltic Devonian terrigenous rocks. In Authigenic Minerals of Baltic Terrigenous Sediments (Pirrus, E., ed.), pp. 25-35. Tallinn (in Russian).

Paluskova, K. 1988. Fossile Verwitterungshorizonte in Vulkaniten Inselgruppe Santorin (Kykladen, Griechenland). Mitteilungen Geol.-Paleont. Institut, Univ. Hamburg, 67, 145-289.

Passier, H. F., de Lange, G. J. \& Dekkers, M. J. 2001. Magnetic properties and geochemistry of the active oxidation front and the youngest sapropel in the eastern Mediterranean Sea. Geophys. J. Int., 145, 604-614.

Pe-Piper, G., Piper, D. J. W. \& Dolansky, L. 2005. Alteration of ilmenite in the Cretaceous sandstones of Nova Scotia, southeastern Canada. Clays Clay Minerals, 53, 490-510.

Plink-Björklund, P. \& Björklund, L. 1999. Sedimentary response in the Baltic Devonian Basin to postcollisional events in the Scandinavian Caledonides. GFF, 121, 79-80.

Shogenova, A. 1999. The influence of dolomitization on the magnetic properties of Lower Palaeozoic carbonate rocks in Estonia. In Palaeomagnetism and Diagenesis in Sediments (Tarling, D. H. \& Turner, P., eds), Geol. Soc. London Spec. Publ., 151, 167-180. 
Shogenova, A. \& Puura, V. 1997. Petrophysical changes caused by dolomitization and leaching in fracture zones of lower Paleozoic carbonate rocks, North Estonia. In Research in Petroleum Technology, Second Nordic Symposium on Petrophysics, Fractured Reservoirs (Middleton, M., ed.), Nordic Petroleum Technology Series, I, 155-185. Nordisk EnergiForskningsprogram, Saghellinga, Norway.

Shogenova, A. \& Puura, V. 1998. Composition and petrophysical properties of Estonian Early Palaeozoic carbonate rocks. In Research in Petroleum Technology (Middleton, M., ed.), Nordic Petroleum Technology Series, IV, 183-202. Nordisk Energi-Forskningsprogram Ås, Norway.

Shogenova, A., Kirsimäe, K., Bitjukova, L., Jõeleht, A. \& Mens, K. 2001. Physical properties and composition of cemented siliciclastic Cambrian rocks, Estonia. In Research in Petroleum Technology (Fabricius, I., ed.), Nordic Petroleum Technology Series, V, 123-149. Nordisk Energi-Forskningsprogram Ås, Norway.

Shogenova, A., Jõeleht, A., Einasto, R., Kleesment, A., Mens, K. \& Vaher, R. 2003a. Chemical composition and physical properties of rocks. In Ruhnu (500) Drill Core (Põldvere, A., ed.), Estonian Geol. Sections, 5, 34-39.

Shogenova, A., Kleesment, A., Jõeleht, A., Shogenov, V. \& Vaher, R. 2003b. Physical properties and composition of Devonian carbonate and siliciclastic rocks from Estonia. In Extended Abstracts, Vol. 2, 65th EAGE Conference and Technical Exhibition, Stavanger. European Association of Geoscientists \& Engineers, 4 pp, P258.

Shogenova, A., Kleesment, A. \& Shogenov, V. 2005. Chemical composition and physical properties of rocks. In Mehikoorma (421) Drill Core (Põldvere, A., ed.), Estonian Geol. Sections, 6, 31-38, Appendixes 2, 14, and 32.

Schneider, J., Bechstädt, T. \& Machei, H. G. 2004a. Covariance of C- and O-isotopes with magnetic susceptibility as a result of burial diagenesis of sandstones and carbonates: an example from the Lower Devonian La Vid Group, Cantabrian Zone, NW Spain. Int. J. Earth Sci. (Geol. Rundsch.), 93, 990-1007.

Schneider, J., de Wall, H., Kontny, A. \& Bechstädt, T. 2004b. Magnetic susceptibility variations in carbonates of the La vid Group (Cantabrian Zone, NW-Spain) related to burial diagenesis. Sedim. Geol., 166, 73-88.

Simaškaite, R. \& Simkevičius, P. 1981. Diagenetic clay minerals in the Middle Devonian Ledai suite deposits of the South Baltic region. In Authigenic Minerals of Baltic Terrigenous Sediments (Pirrus, E., ed.), pp. 123-132. Tallinn (in Russian).

Šliaupa, S., Rasteniene, V., Lashkova, L. \& Shogenova, A. 2001. Factors controlling petrophysical properties of Cambrian siliciclastic deposits of central and western Lithuania. In Research in Petroleum Technology (Fabricius, I., ed.), Nordic Petroleum Technology Series, V, 157180. Nordisk Energi-Forskningsprogram, Ås, Norway.

Šliaupa, S., Hoth, P., Shogenova, A., Huenges, E., Rasteniene, V., Freimanis, A., Bityukova, L., Jõeleht, A., Kirsimäe, K., Lashkova, L. \& Zabele, A. 2003. Characterization of Cambrian reservoir rocks and their fluids in the Baltic States (CAMBALTICA). In Cleaner Energy Systems Through Utilization of Renewable Geothermal Energy Resources (Bujakowski, W., ed.), pp. 61-73. Kajc, Krakow.

Stinkule, A. V. \& Utsal, K. P. 1975. Clay minerals in the Devonian terrigenous beds of the Baltic region. In Geologiya kristallicheskogo fundamenta i osadochnogo chehla Pribaltiki (Lunz, A. J., ed.), pp. 191-291. Zinatne, Riga (in Russian).

Teedumäe, A., Shogenova, A. \& Kallaste, T. 2006. Dolomitization and sedimentary cyclicity of the Ordovician, Silurian, and Devonian rocks in South Estonia. Proc. Estonian Acad. Sci. Geol., $\mathbf{5 5}, 67-87$.

Thomson, J., Higgs, N. C., Wilson, T. R. S, Croudace, I. W., de Lange, G. J. \& van Santvoort, P. J. M. 1995. Redistribution and geochemical behaviour of redox-sensitive elements around S1, the most recent eastern Mediterranean sapropel. Geochim. Cosmochim. Acta, 59, 3487-3501.

Tucker, M. E. \& Wright, V. P. 1994. Carbonate Sedimentology. Blackwell Scientific Publications, London. 
Turekian, K. K. \& Wedepohl, K. H. 1961. Distribution of elements in some major units of the Earth's crust. GSA Bull., 72, 175-192.

Turner, P. (ed.). 1980. Continental Red Beds. Dev. Sedimentol., 29.

Utsal, K. 1971. About the technique and methods in the X-ray investigation of clay minerals. Acta Comment. Univ. Tartuensis, 286, 3-51 (in Russian).

Van Houten, F. B. 1973. Origin of red beds. A review. Annu. Rev. Earth Planet. Sci., 1, 39-61.

Vigliotti, L., Capotondi, L. \& Torii, M. 1999. Magnetic properties of sediments deposited in suboxic-anoxic environments: relationship with biological and geochemical proxies. In Palaeomagnetism and Diagenesis in Sediments (Tarling, D. H. \& Turner, P., eds), Geol. Soc. London Spec. Publ., 151, 71-83.

Weibel, R. 2003. Alternation of detrital Fe-Ti oxides in Miocene fluvial deposits, central Jutland, Denmark. Bull. Geol. Soc. Denmark, 50/2, 171-183.

Wilson, G. S. \& Roberts, A. P. 1999. Diagenesis of magnetic mineral assemblages in multiplyredeposited siliciclastic marine sediments. Wanganui basin, New Zealand. In Palaeomagnetism and Diagenesis in Sediments (Tarling, D. H. \& Turner, P., eds), Geol. Soc. London Spec. Publ., 151, 95-108.

Yamazaki, T., Abdeldayem, A. L. \& Ikehara, K. 2003. Rock-magnetic changes with reduction diagenesis in Japan Sea sediments and preservation of geomagnetic secular variation in inclination during the last 30,000 years. Earth Planets Space, 55, 327-340.

Ziegler, P. A. 1988. Laurussia - the Old Red Continent. In Devonian of the World (McMillian, M. J., Embry, A. F. \& Glass, D. J., eds), pp. 15-48. I Friesen, D. W. \& Sons, Canada.

Zwing, A., Matzka, J., Bachtadse, V. \& Soffel, H. C. 2005. Rock magnetic properties of the remagnetized Palaeozoic clastic and carbonate rocks from the NE Rhenish massif, Germany. Geophys. J. Int., 160, 477-486.

\title{
Diageneetiliste muutuste mõju rauamineraalidele Eesti Devoni karbonaatsetes ja terrigeensetes kivimites
}

\author{
Alla Šogenova ja Anne Kleesment
}

Eesti Devoni karbonaatsed, terrigeensed ja karbonaat-terrigeensed segakivimid on allunud märkimisväärsetele diageneetilistele muutustele. Töö käigus tehtud kaheksa puursüdamiku 165 proovi keemilise ja 10 proovi mineraloogilise röntgenanalüüsi andmed täiendavad varem tehtud 131 proovi mineraloogiliste analüüside tulemusi. Karbonaatkivimite lahustumatu jääk on illiitse, illiit-smektiitse ja kloriitse koosseisuga, millele lisanduvad aktsessoorsete komponentidena biotiit, muskoviit, püriit, götiit, hematiit, sideriit, sfaleriit ja magnetiit. Terrigeensete kivimite olulisteks mineraalideks on kvarts, K-päevakivi, illiit, montmorilloniit, montmorilloniit-kloriit ja kloriit; aktsessoorsete komponentidena lisanduvad biotiit, muskoviit, leukokseen, ilmeniit, püriit, hematiit, götiit ja sideriit. Kivimite rauasisaldus on sedimentatsiooni vältel toimunud terrigeense materjali sissekande ning diageneesiprotsesside käigus toimunud tsementatsiooni, dolomitisatsiooni ja autigeense mineralisatsiooni tulemus. Rauamineraalid muudavad diageneesiprotsessides oma esinemisvormi ja võivad osaliselt alluda ka korrosioonile ning lahustumisele. Seejuures muutuvad valdavaiks kivimi värvust mõjutavad kolmevalentset rauda sisaldavad mineraalid, mille kujunemisele mõjuvad soodustavalt diageneesi 
vältel valitsenud oksüdeerivad tingimused, kuiv kliima ja madal veetase. Hematiitse kattega kvartsterade massilisest esinemisest põhjustatud terrigeensete kivimite punavärvilisus on tõenäoliselt varadiageneetiline, kuid neis kivimeis on toimunud ka hilisemal diageneesil hematiidi moodustumine magnetiidi arvel ja rauaoksüüdide pigmendi moodustumine karbonaatsetes kivimites. Dolokivide ja dolomiitmerglite punavärvilisus on valdavalt varadiageneetiline, eelnedes dolomitisatsiooniprotsessidele, kuid mõningane värvuste muutumine võib olla seotud ka hilisdiageneesiga. Rauamineraalide tekke seostamine erinevate kivimi moodustumise staadiumidega (settimine, vara-, kesk- ja hilisdiagenees) põhineb mineraloogilistel uuringutel immersioonis ja õhikutes, arvestades ka keemilise koosseisu andmeid. Keskmine $\mathrm{Fe}_{2} \mathrm{O}_{3 \text { üld }} / \mathrm{Al}_{2} \mathrm{O}_{3}$ suhe on karbonaatkivimites kõrgem kui terrigeensetes kivimites, mis on vastavuses ka maakoore kohta arvutatud andmetega. See näitab, et rauaühendite ümberjaotumine diageneesil toimub intensiivsemalt just terrigeensetes kivimites. Devoni terrigeensete kivimite $\mathrm{Ti}_{2} \mathrm{O} / \mathrm{Al}_{2} \mathrm{O}_{3}$ ja $\mathrm{K}_{2} \mathrm{O} / \mathrm{Al}_{2} \mathrm{O}_{3}$ suhete väärtused on maakoore keskmistest mõnevõrra kõrgemad, mis võib osutada siin savikivimite muutustele diageneesi käigus. 